Article

\title{
Attitudes and Opinions of Social Media Users Towards Smart Meters' Rollout in Turkey
}

\author{
Yash Chawla ${ }^{1, *,+} \oplus$, Anna Kowalska-Pyzalska $1,+(\mathbb{D}$ and Burcu Oralhan $2 \mathbb{}$ \\ 1 Department of Operations Research and Business Intelligence, Faculty of Computer Science and \\ Management, Wroclaw University of Science and Technology, 50-370 Wroclaw, Poland; \\ anna.kowalska-pyzalska@pwr.edu.pl \\ 2 Faculty of Economics and Administrative Sciences, Nuh Naci Yazgan University, Erkilet Dere Mah., \\ 38170 Kocasinan, Turkey; boralhan@nny.edu.tr \\ * Correspondence: yash.chawla@pwr.edu.pl; Tel.: +48-69-329-0935 \\ + Current address: Wyb. Wyspianskiego 27, 50-370 Wroclaw, Poland.
}

Received: 12 January 2020; Accepted: 4 February 2020 ; Published: 7 February 2020

\begin{abstract}
Increasing the efficiency of electricity transmission is nearing the top of the agenda in many countries around the world. Turkey, the world's most newly industrialized country, is no different. Modernizing the current transmission grids to smart grids (SG) and the national rollout of smart meters (SM), are some of the measures taken by the government to meet the growing demand for electricity. Consumer acceptance and engagement are among the most important elements for the success of SG and SM, however, there have not been much studies done among Turkish electricity consumers. This purpose of this study is to fill this void, by detailing the attitudes, awareness and expectations among Turkish citizens regarding SM and listing recommendations for energy companies based on the findings. Through an online questionnaire, responses from 504 social media users were collected and analyzed. Results show that the consumers are open towards the acceptance of $\mathrm{SM}$, but there is a need to raise awareness and knowledge through proper communication channels. The study has also revealed that a range of conventional and digital channels need to be actively used in order to enhance consumer willingness to accept SM. Increasing social interactions regarding $\mathrm{SM}$ is one of the key recommendations detailed by the authors.
\end{abstract}

Keywords: smart meters; consumer knowledge; Turkish electricity market; social acceptance; social media

\section{Introduction}

Nowadays, in most countries, a great effort is being made to increase the efficiency of electricity generation, transmission and consumption. Governments have proposed some national strategies, legislation and described various ways to achieve the ambitious goals of $\mathrm{CO}_{2}$ reduction, increasing green energy and energy efficiency. These actions are motivated, not only by political (fulfillment of obligations e.g., Paris Climate Agreement) or economic incentives (i.e., lower costs), but also by environmental and social ones. Because of the negative impact of energy intensive industries and energy consumption on climate change, new technologies and a higher level of awareness among people is needed.

The achievement of such goals starts with the national exchange programs of traditional electricity meters into smart ones, allowing for better communication between producers, distributors, sellers and consumers [1-4]. Thanks to smart meters (SM), access to real-time data regarding the electricity consumption is possible [5,6]. From the consumers point of view, access to such information, if combined with varied electricity prices (i.e., different consumption dependent on the time of the 
day, or even real-time prices), may be very valuable and may lead to energy reduction and money savings [7-11].

SM deployment may also bring significant advantages to energy suppliers, by eliminating manual monthly meter readings and enabling the monitoring of the power system in real time. It is also a step towards demand-side management, by introducing dynamic pricing, encouraging more efficient use of the electricity and providing responsive data for balancing electric loads in order to reduce blackouts. Exchange of current meters to SM, in the power system, may also allow the ability to avoid the capital expense of building new power plants by optimizing the usage of the existing resources $[12,13]$.

Turkey observes a growing demand for electricity over the last decade. This is because of increased consumption in both residential as well as industrial sectors. Turkey, which is experiencing rapid industrial growth, is among the countries in the world which are leading producers of agriculture-related products, textiles, automotives, transportation machinery, building materials, home appliances and electronics. Hence, the demand for electricity is bound to increase further. To satisfy the rising demand, Turkish energy companies must ensure the appropriate level of supply and take care of the energy efficiency. Recently, Turkey's largest electricity distribution and retail group-CLK Enerji-announced plans to replace most electricity meters in Turkey with SM. The SM rollout will start with covering four distribution networks in 11 provinces. During this rollout, different SM and communication infrastructure will be tested (https: / / www.dnvgl.com/cases/exploring-smartmetering-in-turkey-85585 (accessed 6 November 2019)). According to the transition plans, prepared by Energy Market Regulatory Authority (EMRA) and Association of Distribution System Operators (ELDER), Turkey would be replacing $80 \%$ of the current electricity meters with SM by 2035 . The primary aim of this transition is to improve the efficient usage of electricity along with reduction in losses and power cuts (for more details see: https: / / balkangreenenergynews.com/turkey-sets-roadmap-smartgrids-plan-worth-over-4-billion/ (accessed 6 November 2019)). As per the roadmap presented in the Turkey Smart Grid 2023 strategy, individual and region specific requirements for the SM upgrade have to be determined by each of the distribution system operators by 2020. Based on individual requirements, the appropriate technology will be applied in each case. The roadmap also takes into account a broader integration of small-scale renewable energy generators within the power system.

Because of the Turkish rollout of SM, there is a great need to investigate the consumers' attitudes and opinions towards this transition. As the literature has proven many times, consumers' acceptance is needed to enhance smooth diffusion of any technology innovation [14-16]. Smart meters themselves are not user-friendly, but if combined with smart metering information systems (platforms, SMP), such as internet widgets or mobile apps, may share the information about electricity consumption (and prices) automatically in real-time $[17,18]$. The access to this information may lead further to some behavioral changes connected with energy conservation.

Within our paper, we plan to explore the current attitudes and expectations towards smart meters of the residential consumers in Turkey. In particular, we focus on social media users, who, based on the up-to-date findings from the literature [19] are a social group, which is perceived to be more open-minded towards innovations and IT-based solutions than the rest of society. We focus on two following research questions: (1) how does the knowledge about SM relate to the consumers' attributes (such as age, education or income), their preferences and fears and willingness to accept/install SM; (2) what are the communication channels used by consumers in order to learn about the energy market and smart meters.

As the literature proves, consumer acceptance and willingness to engage with the technology has the same level of importance as technological advances leading to increase in energy efficiency, if not more $[14,20]$. As far as we are aware from studying the up-to-date literature, the attitudes of Turkish citizens towards SM rollouts have not been extensively investigated. Within this study, we aim to fill in this void. Our paper contributes to the existing literature, not only by adding some valuable information about Turkish SM rollouts, but also by shedding some light on the general determinants of consumers' knowledge about SM and the usage of communication channels between energy companies 
and residential consumers. The article is structured in the following sections: Section 2 details the crucial findings regarding consumers attitudes and opinions towards SM in the light of the up-to-date studies and research. Section 3 details the Turkish transition of the traditional power grid into a smart one, with an emphasis on the role of SM and advanced metering infrastructure (AMI). Section 4 shows the research framework and the methodological background of the study and describes the results. In Section 5, the conclusions and recommendations are presented. Thereafter in Section 6 we describe the limitations of the study and the new horizons it opens for further research.

\section{Consumers' Attitudes towards Smart Grids and Smart Metering: Literature Review}

\subsection{Technology Acceptance}

Among models investigating and explaining the circumstances and the process of technology acceptance, the most popular ones are: unified theory of acceptance and use of technology (UTAUT); technology acceptance model (TAM); value-based adoption model (VAM); and theory of planned behavior (TPB) [21,22]. The comparative analysis of all four models, presented in the work of [21] has shown that for products that are innovative but have minimal practical value (e.g., smart products based on artificial intelligence solutions, to which SM also belongs), the technology acceptance highly depends on consumers' level of interest in technology than in its functional aspects. Dependent on the model, various issues of the decision making process are emphasized. For example, in TAM, the perceived usefulness of the innovation, simplicity in usage and the behavioral intention to use are the major components of the model. The TPB model includes additional attitudes towards the innovation and the subjective norms. The UTAUT and VAM models compare the cost and benefits connected with the innovation adoption (i.e., effort and performance expectancy and enjoyment versus perceived fee) [21]. In exploring consumer acceptance and engagement towards innovative technologies, products and services, Roger's model of innovation diffusion (DoI) is often taken into account [23-28]. In this model, four main elements are integrated: the innovation itself, the social network, in which innovation spreads, as well as the time and communication channels. According to the DoI model, the rate of consumers adoption, that is the number of individuals who have started using a particular innovation in a certain time period, depends on: the innovation's complexity or simplicity, how much can an advancement be experienced with and seen by the others (e.g., neighbors or friends) and compatibility with one's values, needs and past experiences [27,29].

Studies in the literature, on acceptance of smart grid technology, including smart metering and SMP, can be classified into two groups. The first group investigates the main factors and attributes responsible for the smart grids (SG) and SM technology acceptance (see e.g., [1,30]) and the second explores the relations between those factors (see e.g., [15,31]). Among the factors explaining the SG and SM technology acceptance, the literature mentions, apart from financial benefit, eco-friendliness and cyber and privacy security, as well as an understanding of the technology. The researchers emphasize that raising the awareness of consumers and improving the level of information they have on the economic and financial effectiveness of SG would play a major role in the technology acceptance process [22,32].

\subsection{Smart Metering Acceptance}

The transition of the traditional power systems into smart ones will not be possible and effective without the development of smart markets and smart customers [33]. Smart markets include, first of all, advanced metering infrastructure (AMI), metering information management systems, demand management tools and energy trading. Because of those new components of the power system, consumers may now actively engage in the energy market by providing vital inputs from the demand side to balance the grid [34]. In particular, smart meters, combined with enabling technologies, enables the monitoring of energy consumption on a real time basis. In that way, consumers may have a 
positive impact on increasing energy efficiency (i.e., by lowering energy consumption or shifting it from on-peak into off-peak hours) [17].

The role of the electricity customer in the transition of the existing grids into the smart grid is vital. Smart meters installed at each household enable access to the real-time information on consumption for the energy companies as well as for the consumers. The latter may get access to such data mainly through smart metering platforms (SMP), such as web-based interfaces and smartphone applications often combined with in-home displays or intra-networks [17,18,34].

Recently, a lot of studies have been carried out to investigate the social acceptance and awareness of smart grids and smart metering. For consumers, the awareness about the opportunities they get, and the knowledge on how to use SMP, is fundamental. Without any awareness, knowledge and, finally, acceptance of smart metering together with SMP, this novelty will never spread successfully in the market $[11,14,17,35]$, leading to an insufficient increase of energy efficiency. While examining the diffusion of SM, various aspects of its acceptance have been explored, as presented in Table 1.

Generally, studies have revealed that the awareness, interest and knowledge about SM, among residential consumers, is limited all over the world [11,16,34,36,37]. Energy is an abstract commodity, so people do not commonly talk about it [38]. Consumers also have concerns and fears regarding the privacy and security of data provided by SM, installation visits, adverse health consequences, portability in terms of changing suppliers and disconnection of meters on a prepayment basis $[1,8,18,34,39]$. As the literature indicates, most of the consumers' fears rise from the myths and misunderstanding of how SM works. Again, the lack of awareness and knowledge continues to be the main obstacle to the smooth diffusion of SM among residential consumers.

Another aspect of the studies have also shown that rising knowledge about the benefits and options given by SM and SMP may lead to positive behavioral changes (i.e., lower energy consumption or lowering consumption during on-peak hours by shifting it to off-peak hours). The potential of SM is especially emphasized if energy companies provide additional tools for demand-side management and demand response (DSM/DR), such as dynamic electricity tariffs. In that case, feedback received via SM and SMP, regarding electricity consumption as well as prices, may have a great impact on the increase of energy efficiency $[10,40]$. On the other hand, there is uncertainty regarding persistence of the consumers' engagement, where it would sustain over a longer period of time or will disappear due to the discouragement and lack of motivation [17,34,41].

Finally, although there is a large portion of studies investigating the effectiveness of feedback provided by SM and SMP (see for example $[9,10,38,40,41]$ ), there are very few papers exploring the role of communication channels (traditional versus modern ones) in terms of SM diffusion (e.g., [42,43]. Within our paper we want to fill this gap. 
Table 1. Literature review: research aspects of the consumers' acceptance and engagement towards smart meters (SM) and smart metering platforms (SMP).

\begin{tabular}{lll}
\hline Issue Investigated & Citation & Summary of Findings \\
\hline Consumers' acceptance & {$[1,15,30,31$,} & $\begin{array}{l}\text { The acceptance starts with some level of awareness and knowledge. } \\
\text { and engagement }\end{array}$ \\
& & $\begin{array}{l}\text { So far, many of the consumers are unfamiliar with the terms SG and } \\
\text { SM. Consumers express interest in conserving energy, but usually do not } \\
\text { know how to achieve this goal. Consumers are willing to accept SM if it } \\
\text { enables them to save energy (and money), has no negative effect on one's } \\
\text { health and does not increase privacy concerns and fears. The privacy } \\
\text { concern due to access to the private information about one's usage of } \\
\text { electricity and hence, presence at home, and the health concern, as a } \\
\text { result of increased electromagnetic exposure or wireless smart meters, } \\
\text { belong to the most common disadvantages of SM. }\end{array}$ \\
\hline
\end{tabular}

Willingness to pay for $[11,34,36,47]$ Consumers are interested in SM especially if they do not need to pay for $\mathrm{SM}$ /willingness to install implementation. They also expect receiving an access to some supporting $\mathrm{SM}$ technologies (such as in-home displays or SMP) in order to optimize energy usage. They appreciate high levels of automatic adjustment of energy consumption of their home appliances, as in most cases they do not want to pay much attention to current electricity prices and hence adjust their consumption behaviors and habits.

Incentives and barriers to $\quad[1,16,31,32, \quad$ To the most common barriers belong: consumers decision making based adoption $34,39,48] \quad$ on limited information, uncertainty of choice, lack of knowledge and understanding leading to negative perceptions and beliefs, negative word of mouth, discomfort of usage (e.g., change of habits) and privacy and security concerns. Among most popular incentives there are the willingness to protect the environment, to save energy and money and to adjust to social norms.

Effectiveness of feedback $\quad[7,9,10,17,18, \quad$ In most cases only consumers who are predominately aware of what SM provided by SM 40,41,49] is, are interested in receiving feedback about their energy consumption. It is still not clear how to attract consumers' attention and engagement in a longer time period, especially if the achieved savings are not very impressive. The perceived possibility to monitor energy via SM and SMP has a great impact on adoption.

The role of knowledge, [50,51] Knowledge and awareness of SM and SMP are mainly influenced by: effectiveness of education advertising, social impact and education and training. In addition, and training a certain level of skills related to the usage of an internet platform or a mobile application is required to use SMP. To attract consumers to SMP, providers of those services should rather apply training and educational programs tailored to individual groups of consumers, rather than general education and marketing campaigns. The manipulation of the time that the consumer needs to make a decision (e.g., by means of promotion in a given time interval) affects the rate of diffusion. It is also crucial to maintain the appropriate level of knowledge and skills among consumers, acquired during training, for example by reminding them about SMP by means of text messages, e-mails or information brochures.

Role of communication $[18,32,42,43, \quad$ Outreach and communication should try to increase familiarity and channels 52,53] demonstrate the financial and environmental benefits of SM and SG. At present both, the outreach and communication between energy providers and the consumers are insufficient to improve the understanding of SM and its effective usage. Social media nowadays seems to be a convenient medium for using social impact and spreading information about the innovative solutions, applications and services.

\section{Smart Grids in Turkey}

\subsection{Turkish Electricity Market}

The Turkish electricity market, as described by Colak et al. [54], has followed typical mile steps in its development: starting with the unbundling of the generation, transmission and distribution in 1994, through the establishment of EMRA (Energy Market Regulatory Authority) and a few levels of market opening between 2004 and 2011. 
Nowadays, in Turkey, the Ministry of Energy and Natural Resources and Republic of Turkey Energy Market Regulatory Authority (EPDK) are responsible for the energy policies. These government departments have completed the necessary studies and have been conducting various projects to adjust the existing power system and the current energy market infrastructures to smart grid concept [55].

\subsection{Establishment of Smart Grids}

The beginning of the smart grid approach towards the Turkish power system began around ten years ago by means of a policy proposed by the Turkish Ministry of Energy in the so-called Natural Resources Strategic Plan (2010-2014). This strategy aimed to increase the share of renewable energy within the energy supply without stating in detail the role of smart grid in reaching this aim $[54,56]$.

Shortly after 2014, Turkish distribution system operators (DSO) started some pilot projects aimed at advanced metering infrastructure (AMI), including smart meters (SM), but also DSM/DR tools. Currently, the government proposed a project called Turkey Smart Grid 2023 Vision and Strategy Roadmap (TSG2023), which is going to be implemented in the years 2016-2020. This roadmap is aimed at providing directions on the 2035 smart grid vision to the distribution companies, in short and medium terms, by pointing out the necessary priorities [33]. According to the TSG2023 roadmap, at least $80 \%$ of customers should be equipped with SM in the coming years (Read more in: Turkey Smart Grid 2023 Vision and Strategy Roadmap Summary Report, (2018). Republic Of Turkey Energy Market Regulatory Authority, Strategy Development Department Ankara, Turkey).

\subsection{Smart Grid Pilot Projects}

Turkey has embarked on the development of smart system technology and some initiatives have already taken solid steps in this direction [57]. First of all, as already mentioned, there is a vision and implementation process starting with the rollout of smart meters. This rollout has been started by the Turkish Electricity Transmission Corporation (TEİASS) and is then being continued within the distribution companies in Turkey (Akcanca, M. A., and Taşkın, S. (2011). Akıllı şebeke uygulanabilirliği açısından türkiye elektrik enerji sisteminin incelenmesi. Akıllı Şebekeler ve Türkiye Elektrik Şebekesinin Geleceği Sempozyumu, 26-27. (in Turkish)). In TEİAŞ, the Automatic Meter Reading System (OSOS) project has also been carried out for the remote automatic reading of the smart meters belonging to the users of the electricity transmission system. With the provisional acceptance of the project, at of the end of 2012, automatic data collection via OSOS was performed from approximately 2761 digital electricity meters installed in 948 different locations (TEİAŞ, Annual Activity Reports, http: //www.teias.gov.tr/FaaliyetRaporlari.aspx, 13 October 2013 (accessed 5 November 2019)). Within this project, the real-time monitoring system was developed throughout the country. Real-time monitoring of all electrical magnitudes and power quality parameters of the electricity transmission system has been realized [58].

\subsection{Attitudes of Turkish Citizens to SG}

The smart grid concept, together with the introduction of SM and SMP is still a great novelty in the Turkish energy market. Most consumers are not familiar with the Turkey Smart Grid and Vision roadmap for 2030. In the SWOT analysis of smart grid infrastructure in Turkey, Colak et al. [54] have emphasized that the lack of consumer awareness about the smart grid contributes to one of its most significant weaknesses for implementation.

Although the opinions of Turkish residential consumers have not been investigated extensively, in the work of Tumbaz et al. [59], the attitudes and behaviors in the smart grid context have been explored. In particular, the authors have found that the energy consumption patterns of households may lead to the identification of potential electricity savings in the residential sector, such as standby consumption and potential electricity use, which can be shifted to off-peak hours. Moreover, the authors have driven some specific policy recommendations, which can promote behavioral change by measuring the responsiveness of people to different measures and the 
combination of measures, such as information, feedback, rewards and social influences. The results obtained from this survey were used to depict a general view of Turkish households towards electricity consumption behaviors and their energy efficiency attitudes. They clearly indicate that there should be more regulations and improvements in energy policy [59] in order to increase the responsiveness level of Turkish electricity consumers.

Taking all of that into consideration, by the means of our study, we seek to explore the current attitudes and expectations of Turkish citizens, regarding smart meters, even further. There are two research questions we seek to answer: (1) how does knowledge about SM relate to the consumers' attributes (such as age, education or income), their preferences and fears and willingness to accept/install SM; (2) what are the communication channels used by the consumers in order to learn about the energy market, in general, and smart meters, in particular.

As mentioned earlier, the examination of consumers' knowledge and its determinants on SM acceptance is important. Knowing what is important for the consumers may then lead to a better presentation of the advantages and opportunities of SM by energy companies. Moreover, the investigation of communication channels, preferred by the consumers in the energy context, may enable better communication between energy companies and their residential customers.

\section{Method, Results and Discussion}

\subsection{Methods}

The research and survey framework adapted the methods followed by previous research [23-26,34]. As mentioned in Section 2.1, there are a few models explaining the technology acceptance. In our survey, we focus mostly on the diffusion of innovation (DoI) model given by Roger in 2003 [27]. In this model, four main elements are integrated: the innovation itself, the social network (environment), in which innovation spreads, as well as the time and communication channels. In our approach, we focus on two elements of the model: the social network and the communication channels. According to Roger's model, market participants can be divided into certain groups, dependent on their propensity to adopt innovative initiatives $[27,28]$. The first group that plays a vital role in diffusing the innovation is described as early adopters. In case of smart meters and the enabling technology combined with them (e.g., in-home displays, mobile apps or smart plugs), the early adopters are usually consumers who are more experienced with mobile apps and other smart devices. We believe that social media users-people who are active in their social networks and use mobile apps on a regular basis, are expected to be open-minded and eager to use the new equipment or applications $[19,60]$. That is why our study is focused on and conducted among social media users.

Figure 1, shows the research and survey frameworks and the variables we used. Variable choice has been inspired by the literature review as well as our research questions. In particular, similar to the other studies, we include the group of socio-demographic variables (D1-D10), preferences and willingness to adopt SM under different circumstances (P1-P4, De1-De8, G1-G3, X1), attitudes towards energy saving and environment (A2, A31-A39) and awareness and knowledge about SM (K1-K4). What is more rare in the context of smart metering, but common to the studies of innovation diffusion, we have also included the set of possession of smart devices and personal assets (B1-B7, R1), as well as behaviors towards buying a new technology (A1) and many questions regarding communication channels and sources of information in terms of the energy market in general and SM in particular (S01-S08, S1-S15, I1, I2, I31-I45, Q1, Q21-Q35). All the variables are listed and described in Table A1 (Appendix A). In total, the proposed questionnaire refers much to the Roger's DoI model, by including social influence and communication channels in the questions asked.

To collect the data from the respondents, the survey was conducted in the form of a self-administered online questionnaire which the respondents had to fill in three phases, as shown in the survey framework and variable part of Figure 1. The questionnaire could be accessed in both the English and Turkish languages, for the convenience of the residents of Turkey. At first, a convenience 
sampling method was used and the questionnaire was distributed through social media platforms such as Facebook, LinkedIn, Twitter, Facebook Messenger, WhatsApp and so on. E-mails were also sent by the author(s), through their connections. Thereafter the snowball sampling method was used, wherein the respondents who were contacted at first, were requested to disseminate the questionnaire to their social and professional network. In total, $\mathrm{N}=504$ responses were collected between 10 September 2019 and 10 October 2019, 502 in Turkish and only 2 in English. A total of 1415 landings were recorded on the homepage where the respondents had to choose the language of their choice, out which 1303 proceeded to the page in Turkish, 13 navigated to the page in English, whereas the rest dropped out from the landing page itself.

Once the data was collected, all of it was translated back to English language. Thereafter we analyze the demographics to describe the sample and show that it is representative (see Section 4.2).

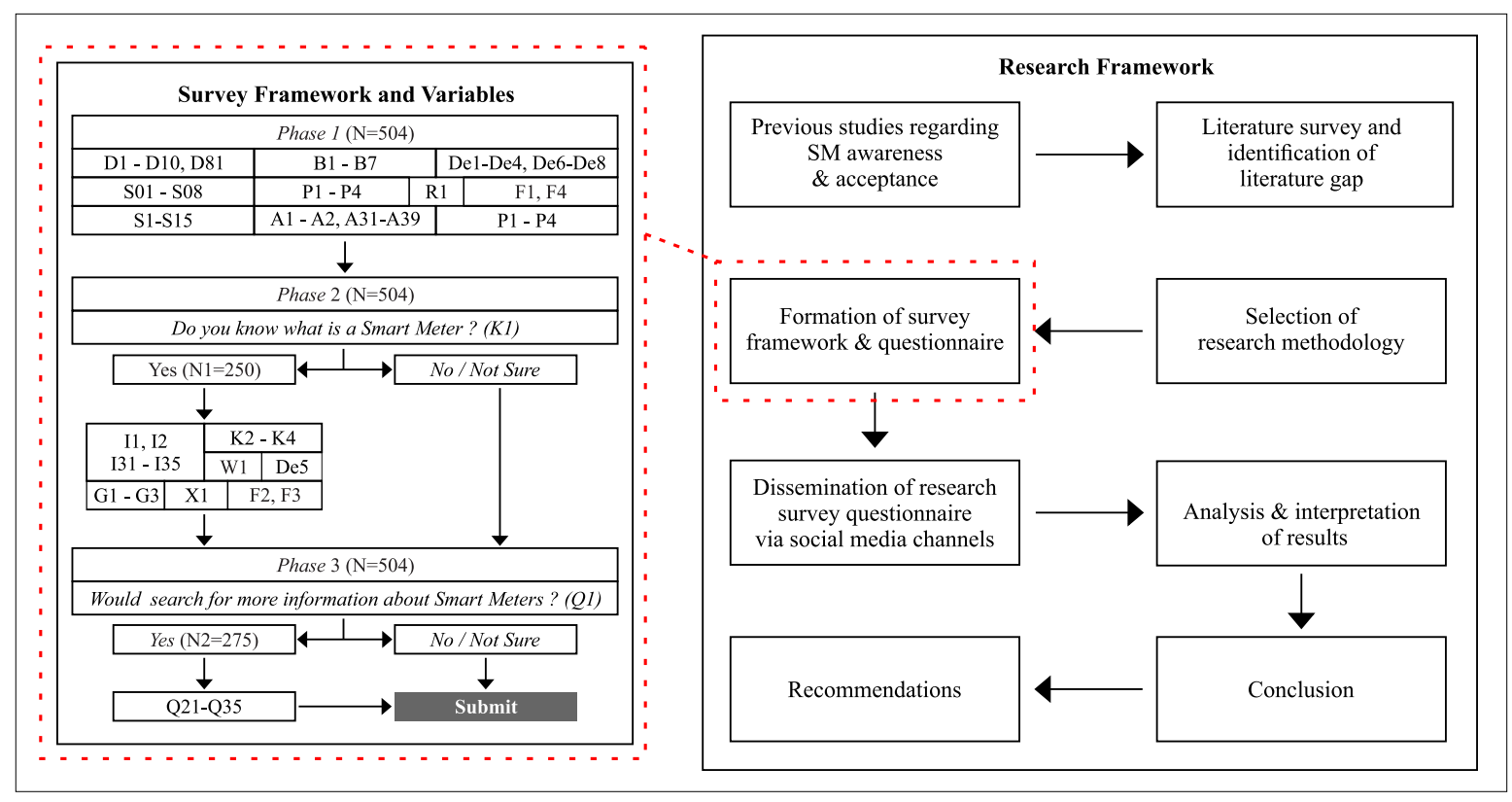

Figure 1. Research framework.

We analyzed the attitudes and opinions of the respondents towards the environment, buying new technology innovation, knowledge about SM, preferences and conditions under which they would accept SM and communication channels they would prefer to use while seeking more information about SM, independently. After that we created a binary Logit model, with a dependent variable as the knowledge about SM (K1) and the other variables as the regressors.

\subsection{Description of the Sample}

The collected sample of Turkish nationals and residents is represented by both male and female (4:3) who are primarily either single or married and are between the 18 to 35 years of age. Majority of them have at-least a high school diploma or have completed a bachelor degree. A large number of the respondents are unemployed, whereas the other are employed in public or private sectors. A small number of respondents also have their own business. Cross tabulation of age with the gender, relationship status, educational level and employment status, shown in Table 2. 
Table 2. Cross tabulation of Age in Year (D2) with Gender (D1), Relationship Status (D3), Educational Level (D4) and Employment Status (D5).

\begin{tabular}{|c|c|c|c|c|c|c|c|c|}
\hline \multirow{2}{*}{ Code } & \multirow{2}{*}{ Variable Options } & \multicolumn{6}{|c|}{ Age in Years (D2) } & \multirow{2}{*}{ Total } \\
\hline & & $18-25$ & $26-35$ & $36-45$ & $46-55$ & $56-65$ & $66+$ & \\
\hline \multirow{2}{*}{$\overrightarrow{\bar{a}}$} & Male & 146 & 64 & 32 & 18 & 25 & 3 & 288 \\
\hline & Female & 96 & 55 & 34 & 27 & 4 & 0 & 216 \\
\hline \multirow{5}{*}{$\tilde{\rho}$} & Single & 177 & 28 & 9 & 1 & 1 & 0 & 216 \\
\hline & In a Relationship & 55 & 12 & 0 & 1 & 0 & 0 & 68 \\
\hline & Married & 10 & 77 & 54 & 38 & 27 & 2 & 208 \\
\hline & Separated/Divorced & 0 & 2 & 2 & 3 & 0 & 0 & 7 \\
\hline & Widowed & 0 & 0 & 1 & 2 & 1 & 1 & 5 \\
\hline \multirow{6}{*}{$\ddot{D}$} & No formal education & 0 & 0 & 0 & 0 & 0 & 0 & 0 \\
\hline & Primary School Only & 1 & 1 & 1 & 2 & 1 & 0 & 6 \\
\hline & High School Pass & 106 & 12 & 12 & 6 & 6 & 1 & 143 \\
\hline & Bachelor Complete & 126 & 75 & 33 & 31 & 21 & 2 & 288 \\
\hline & Masters Complete & 9 & 24 & 12 & 2 & 1 & 0 & 48 \\
\hline & PhD complete & 0 & 7 & 8 & 4 & 0 & 0 & 19 \\
\hline \multirow{6}{*}{$\stackrel{\llcorner}{\circ}$} & Job in Private Sector & 59 & 57 & 34 & 11 & 8 & 0 & 169 \\
\hline & Job in Public Sector & 3 & 33 & 16 & 21 & 6 & 0 & 79 \\
\hline & Business & 11 & 7 & 8 & 0 & 0 & 0 & 26 \\
\hline & Student & 0 & 0 & 0 & 0 & 0 & 0 & 0 \\
\hline & Unemployed & 169 & 22 & 8 & 7 & 0 & 0 & 206 \\
\hline & Retired & 0 & 0 & 0 & 6 & 15 & 3 & 24 \\
\hline
\end{tabular}

Note: Cells in the table, highlighted in yellow, depict the majority of the sample.

The net household income of large majority of the respondents is lower than 10,000 TL and they pay between 0 and $325 \mathrm{TL}(1 \mathrm{TL}=0.17 \mathrm{USD}$ ) for their monthly electricity consumption. They live in apartment or flats in multi-storied buildings. The cross tabulation in the Table 3 shows the distribution of relative respondents between the two variable pairs, D6 with D7 and D9 with D7.

Further, we cross tabulated the area of residence of the respondents with the number of members in the household, number of children and the type of residence they live in, shown in Table 4. It shows a that large part of the respondents are from cities with populations of more than 500,000, with 2 to 5 members living in the household and more than $60 \%$ having no children. The most common type of residence is an apartment or a flat in a multi-storied building, as mentioned in the previous paragraph.

As the study was carried out among Turkish social media users, we compared the demographics of the respondents in this study with the demographics of the social media users in Turkey, to show that the sample is representative. A large majority of social media users in Turkey are young, between the age of 18 to 35, have at least a high school diploma, are either unemployed or are in private sector jobs and live in cities (for more details see: https://datareportal.com/reports/digital-2019-turkey (accessed: 8 January 2020)). The highlighted sections in Table 2, correspond to the majority of the respondents in this study as well as the demographics of Turkish social media users in actual, hence we can consider the data to be representative. 
Table 3. Cross tabulation of monthly net household income in TL (D6) and type of residence (D9) with the month electricity expense in TL (D7).

\begin{tabular}{|c|c|c|c|c|c|c|c|c|}
\hline \multirow{2}{*}{ Code } & \multirow{2}{*}{ Variable Options } & \multicolumn{6}{|c|}{ Monthly Electricity Bill (D7) } & \multirow{2}{*}{ Total } \\
\hline & & 0 & 1 & 2 & 3 & 4 & 5 & \\
\hline \multirow{12}{*}{ ค̊ } & Prefer Not to Say & 14 & 21 & 12 & 2 & 0 & 1 & 50 \\
\hline & $0-2500$ & 1 & 78 & 21 & 0 & 1 & 0 & 101 \\
\hline & $2501-5000$ & 3 & 112 & 34 & 2 & 0 & 1 & 152 \\
\hline & $5001-7500$ & 0 & 75 & 31 & 0 & 0 & 0 & 106 \\
\hline & $7501-10,270$ & 0 & 32 & 14 & 0 & 0 & 0 & 46 \\
\hline & $10271-14,885$ & 0 & 13 & 16 & 0 & 1 & 1 & 31 \\
\hline & $14,886-17,550$ & 0 & 3 & 3 & 0 & 1 & 1 & 8 \\
\hline & $17,551-21,450$ & 0 & 1 & 1 & 1 & 0 & 0 & 3 \\
\hline & $21,451-27,072$ & 0 & 0 & 1 & 0 & 0 & 0 & 1 \\
\hline & $27,073-40,014$ & 0 & 1 & 4 & 0 & 0 & 0 & 1 \\
\hline & $40,015-53,950$ & 0 & 3 & 0 & 0 & 0 & 0 & 3 \\
\hline & more than 53,950 & 0 & 2 & 0 & 0 & 0 & 0 & 2 \\
\hline \multirow{4}{*}{ ค่ } & Apartment/Flat* & 2 & 48 & 21 & 0 & 0 & 1 & 72 \\
\hline & Apartment/Flat ** & 15 & 275 & 95 & 4 & 2 & 2 & 393 \\
\hline & House $^{+}$ & 0 & 7 & 5 & 0 & 0 & 0 & 12 \\
\hline & House $^{++}$ & 1 & 11 & 12 & 1 & 1 & 1 & 27 \\
\hline
\end{tabular}

${ }^{*}$ In a building of 4 floors or less. ${ }^{* *}$ In a building with more than 4 floors. ${ }^{+}$Only group floor. ${ }^{++}$Multiple floors. Note: Cells in the table, highlighted in yellow, depict the majority of the sample.

Table 4. Cross tabulation of Age in Year (D2) with Gender (D1), Relationship Status (D3), Educational Level (D4) and Employment Status (D5).

\begin{tabular}{|c|c|c|c|c|c|c|c|}
\hline \multirow{2}{*}{ Code } & \multirow{2}{*}{ Variable Options } & \multicolumn{5}{|c|}{ Area of Residence (D10) with Population in Brackets $(k=1000)$} & \multirow{2}{*}{ Sum } \\
\hline & & Village & City $(<50 k)$ & City (50k-100k) & City (100k-500k) & City (>500k) & \\
\hline \multirow{6}{*}{$\stackrel{\infty}{\circ}$} & One & 0 & 2 & 2 & 2 & 27 & 33 \\
\hline & Two & 1 & 3 & 6 & 5 & 43 & 58 \\
\hline & Three & 5 & 7 & 10 & 12 & 106 & 140 \\
\hline & Four & 2 & 4 & 9 & 13 & 131 & 159 \\
\hline & Five & 1 & 4 & 4 & 9 & 64 & 82 \\
\hline & Six or More & 1 & 1 & 7 & 7 & 16 & 32 \\
\hline \multirow{5}{*}{$\vec{\infty}$} & None & 5 & 9 & 21 & 32 & 243 & 310 \\
\hline & One & 3 & 5 & 6 & 5 & 45 & 64 \\
\hline & Two & 1 & 3 & 6 & 8 & 69 & 87 \\
\hline & Three & 0 & 3 & 4 & 3 & 26 & 36 \\
\hline & Four or More & 1 & 1 & 1 & 0 & 4 & 7 \\
\hline \multirow{4}{*}{ คิ } & Apartment/Flat* & 1 & 12 & 10 & 3 & 46 & 72 \\
\hline & Apartment/Flat ** & 0 & 7 & 24 & 42 & 320 & 393 \\
\hline & House $^{+}$ & 5 & 0 & 2 & 1 & 4 & 12 \\
\hline & House ${ }^{++}$ & 4 & 2 & 2 & 2 & 17 & 27 \\
\hline
\end{tabular}

${ }^{*}$ In a building of 4 floors or less. ${ }^{* *}$ In a building with more than 4 floors. ${ }^{+}$Only group floor. ${ }^{++}$Multiple floors. Note: Cells in the table, highlighted in yellow, depict the majority of the sample.

To make sure even more that the data is representative in terms of the usage of various social media platforms, we have asked the respondents about the social media platforms they were active on. 
Figure 2 shows the percentage of respondents (in this study) active on various social media platforms and the percentage of Turkish internet users active on the same social media platforms (for more details see: https:/ / datareportal.com/reports / digital-2019-turkey (accessed: 8 January 2020)), which are quite similar.

The average household income and the expenditure of electricity bills of a Turkish household, shown in Table 3, also corresponds to the actual average of a Turkish household (For more details see: http:/ / www.oecd.org/economy/surveys/Turkey-2018-OECD-economic-surveyoverview.pdfandhttps://www.guidesglobal.com/utilities-in-turkey/ (accessed: 8 January 2020)). Finally, the average number of members in household, household type and average number of children, shown in Table 4, also coincide with the actually numbers in Turkey (for more details see: https:/ /ec. europa.eu/eurostat/statistics-explained/index.php/Household_composition_statistics (accessed: 8 January 2020)). Hence, the data collected in this study can be considered as representative of the social media users in Turkey.

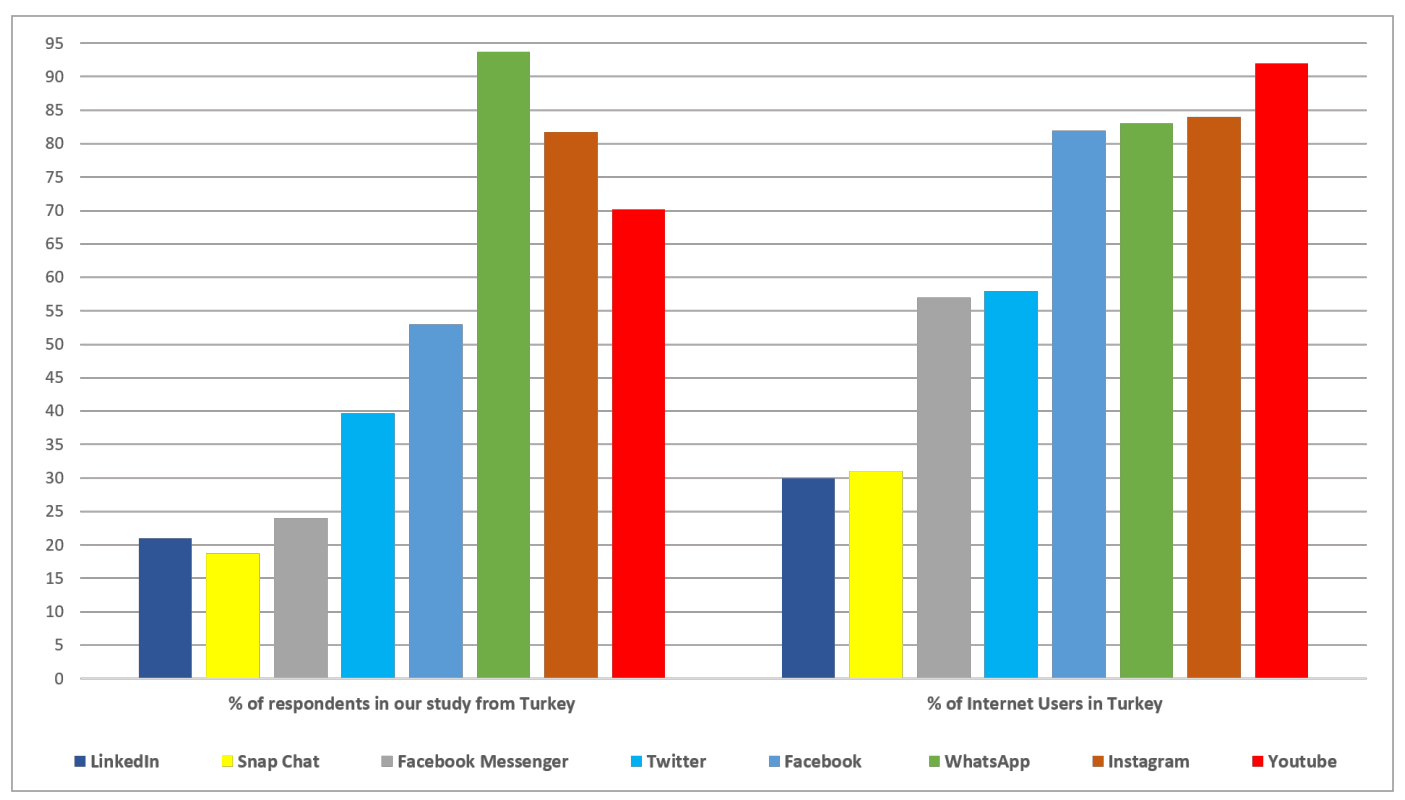

Figure 2. Percentage of users active on various social media platforms.

\subsection{Knowledge about $S M$}

A total of 250 out of the 504 respondents, just shy of $50 \%$ of the sample, indicated that they knew what an SM was. Of these 250, 67 already have an SM installed at home, whereas 24 are in the process of having an SM installed and 45 have a plan of getting an SM installed at their homes. This indicated that still, almost $50 \%$ of the respondents who know what an SM is, neither have an SM installed, nor have any plans of having SM installed at their homes. But still, over $60 \%$ of those who knew what an SM was expressed that they would like to have an SM installed at their home, a majority of which were those who were positive towards $\mathrm{K} 2$, $\mathrm{K} 3$ or $\mathrm{K} 4$.

\subsection{Belongings and Assets}

Figure 3 shows the mean and standard deviation of the belongings and assets (B1-B7) of the respondents. Respondents were either in possession of or were planning to buy a B2-flat or apartment $($ Skewness $=-0.825$, Std. Error $=0.109)$, B3-a laptop (Skewness $=-1.794$, Std. Error $=0.109)$, B4-wifi or internet connection at home (Skewness $=-2.719$, Std. Error $=0.109$ ) and B5-home appliances that can connect to the internet (Skewness $=-1.936$, Std. Error $=0.109$ ). At the same time, the respondents did not possess and were not even planning to buy B1-a house, B6-electric vehicle and B7—smart 
technologies that enable energy consumption or monitoring (Skewness $=1.122,2.273$ and 1.341 respectively with Std. Error $=0.109$ ).

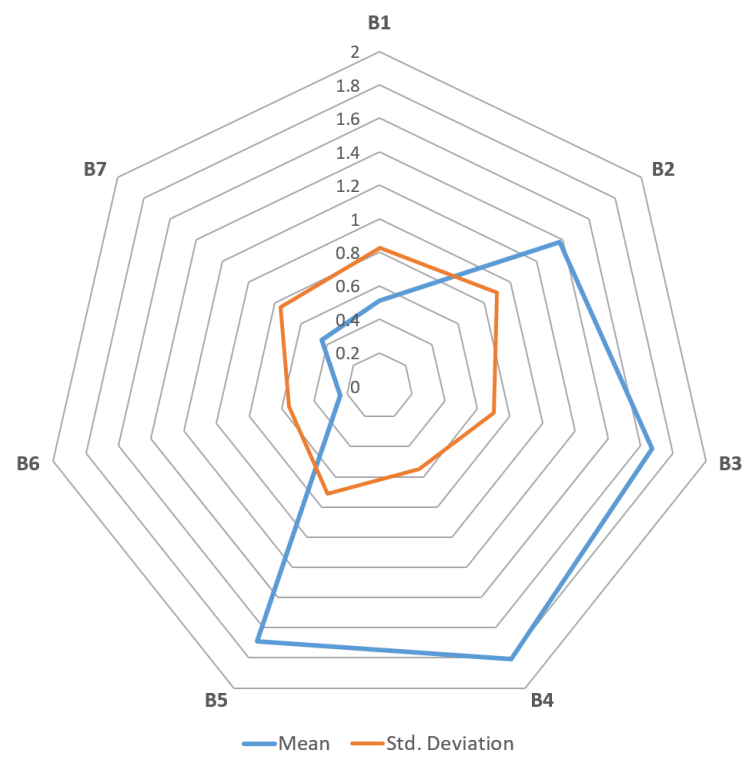

Figure 3. Mean and standard deviation of belongings and assets of the respondents.

\subsection{Attitude and Behavior towards Pro-Environmental Activities}

The analysis of the variables A1, A2 and A31-A39 revealed that, in terms of upgrading their home appliances with newer versions $(\mathrm{A} 1-\mathrm{Mean}=1.21, \mathrm{SD}=0.75)$ and buying new phones to get latest technologies $(\mathrm{A} 2-\mathrm{Mean}=1.63, \mathrm{SD}=1.006)$, the respondents favored longer use of technology. They upgrade home appliances with new ones, once in three years or more, and new mobile phone in a bit lesser duration i.e., in two or more years. To confirm that this buying behavior was not dependent on the household income (D6), we checked the correlations between D6 and A1 and D6 and A2, which was found to be insignificant.

A total of $21.5 \%$ of respondents also reported to have renewable energy sources installed at home, with no significant correlation with household income or knowledge about SM nor the monthly electricity expenses. Table 5 shows the responses towards various behavioral questions and the mean of the responses (No - 0 and Yes - 1). It can be seen that majority of the respondents are involved in activities which are pro-environmental and are in favor of energy saving, as the mean values of 7 out of the 9 activities are over 0.5 . 
Table 5. Mean values of variables A31-A39 $(\mathrm{N}=504)$.

\begin{tabular}{lc}
\hline Activity & Mean \\
\hline (A31) I follow organizations or profiles on social media that promotes saving of energy & 0.27 \\
\hline (A32) I have searched on the internet about how to live in a eco-friendly living way & 0.46 \\
\hline (A33) I reuse grocery bags & 0.89 \\
\hline (A34) I have invested in energy saving appliances for my home & 0.57 \\
\hline (A35) I regularly monitor energy consumption at home & 0.7 \\
\hline (A36) I segregate garbage at home & 0.69 \\
\hline (A37) I have returned home, sometimes, to ensure that I switched off the home appliances or the lights etc. & 0.79 \\
\hline (A38) I have paid more for buying a more energy efficient appliance & 0.6 \\
\hline (A39) I have picked up trash left by somebody else while being outdoor & 0.85 \\
\hline
\end{tabular}

\subsection{Preferences and Attitude towards Acceptance of SM}

$\mathrm{SM}$, combined with in-home displays or mobile applications and other devices, offer benefits such as a detailed depiction of consumption of electricity, real time information on the consumption of electricity, ability to switch on/off supply and monitor tariffs in case of fluctuating unit rates [61]. Preferences of the respondents indicate that they would like to have these benefits. A total of $70.8 \%$ of the respondents desired to get more information about their use of electricity, $72.2 \%$ respondents said that having real time information of energy consumption would be useful for them, $81 \%$ respondents would like to have the ability of controlling the power supply to the appliances through mobile application and $76.4 \%$ respondents would prefer to have fluctuating unit rates for electricity during the day, so that they can consume more when electricity is cheaper.

We asked the respondents that knew what an SM was, whether they would prefer the government to make it mandatory to install an SM for everyone. The response was pretty even with $49.2 \%$ opposing, whereas the rest were in favor of it. In an additional question asked to confirm this, over three quarters (79.6\%) of the respondents wanted the government to offer SM as an option. A significant minority (13.6\%) of the respondents also expressed the intention to protest if they did not have an option to say no to installing SM at their home. The same respondents were asked if they knew about government's national rollout program for SM and 76\% of them did not know about it. We checked the correlations between having information about the national rollout program (I2) and their preferences towards governmental policy (G1, G2 and G3), through Kendall's Tau B test, which showed that there is a high and statistically significant relation between them. Increase in the information about the national rollout program increases the probability of consumers accepting the government making it mandatory to install SM for all residents (correlation co-efficient: 0.160 and $p$-value (2-tailed): 0.12 ).

\subsection{Fears towards Acceptance of SM}

Previous studies have shown the consumers have fears regrading their data privacy, health effects and inaccurate billing $[11,34,44,45,62,63]$. In some cases the consumers have a fear of coping with the change (for instance from current meters to SM), because they feel that such changes result in increased expenses [64]. In this study we found that over half (51.59\%) of the respondents had fear of privacy breach (F1) if companies had access to the data of their detailed electricity usage. Additionally over $43 \%$ of respondents had concerns about increased stress (F4) on them due to fluctuations in electricity prices. Among the respondents who indicated to have knowledge about $\mathrm{SM}$, over $64.4 \%(\mathrm{~N} 1=250)$ 
raised concern about inaccurate billing, whereas only $6 \%$ of respondents had a fear of any adverse effect on health because of SM.

\subsection{Willingness to Accept SM under Different Conditions}

The respondents willingness to accept the installation of SM under various conditions was found to vary (see, Figure 4) between a mean as low as 0.0814 to as high as 0.8631 . Respondents were highly willing to accept $\mathrm{SM}\left(D_{e} 1\right)$ if they were convinced that $\mathrm{SM}$ would help them save energy and money. This did not have statistically significant correlation with the household income (D6) or the monthly electricity expenses (D7). The willingness to install SM is at its lowest when the respondents feel that there might be some adverse effect on health $\left(D_{e} 2\right)$ even if they would be able to save on electricity bills.

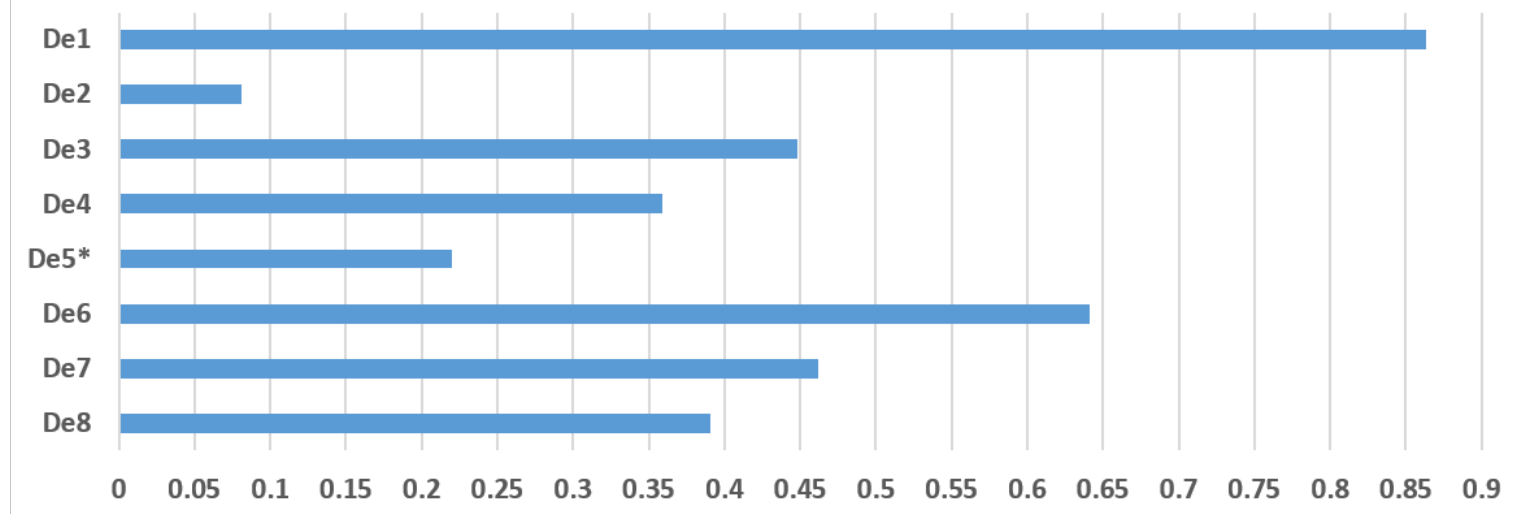

Figure 4. Mean values of $D_{e} 1-D_{e} 8 .{ }^{*}$ For $D_{e} 5$ we have N1 $=250$.

In terms of energy companies having access to data of energy usage $\left(D_{e} 3\right)$, over half of the users are concerned with the data privacy issues. We found a statistically significant correlation (coefficient: $-0.22, p: 0.000)$ between the concern regarding data privacy (F1) and $D_{e} 3$. It was also interesting to observe similar numbers in comparing the cross tabulations of variables $\mathrm{F} 1$ and $D_{e} 3$ for the respondents with $\mathrm{K} 1=0$ and $\mathrm{K} 1=1$, shown in Tables 6 and 7 respectively. This shows that near $20 \%$ of all the respondents, are having a data privacy concerns but are still willing to accept SM if it helps them save on electricity bills. Just over $10 \%$ of the respondents do not have privacy concerns, in case the energy companies had access to their consumption data but are not willing to accept installation of SM under this condition.

A visit from a company representative $\left(D_{e} 4\right)$ or recommendation from a friend, family member or colleague $\left(D_{e} 7\right)$ would convince around $45 \%$ of the respondents to accept installation of SM. About $40 \%$ of respondents were willing to install SM if a friend, a family member or a colleague has installed SM at their home $\left(D_{e} 8\right) . D_{e} 7$ and $D_{e} 8$ are significantly related to each other (coefficient: $0.513, p: 0.000$ ) which indicates that social influence for the willingness to accept SM would be about $50 \%$ higher if the person making the recommendation has an SM installed at his/her home. Willingness to accept SM is high, at nearly $65 \%$ if the installation of SM or upgrade to SM is free for the consumers. Among the respondents who have knowledge about $\mathrm{SM}$, approximately $22 \%$ are willing to accept $\mathrm{SM}$ even if they have to pay for having SM at their home $\left(D_{e} 5\right)$.

Table 6. Cross tabulation of variables $\mathrm{F} 1$ and $D_{e} 3$, for respondents with $\mathrm{K} 1=0$.

\begin{tabular}{ccccc}
\hline & & \multicolumn{3}{c}{$\boldsymbol{D}_{\boldsymbol{e}} \mathbf{3}$} \\
\cline { 2 - 5 } & & $\mathbf{0}$ & $\mathbf{1}$ & Total \\
\hline \multirow{3}{*}{$\mathrm{F} 1$} & $\mathbf{0}$ & 59 & 59 & 118 \\
\cline { 2 - 5 } & $\mathbf{1}$ & 87 & 49 & 136 \\
\cline { 2 - 5 } & Total & 146 & 108 & 254 \\
\hline
\end{tabular}


Table 7. Cross tabulation of variables $\mathrm{F} 1$ and $D_{e} 3$, for respondents with $\mathrm{K} 1=1$.

\begin{tabular}{ccccc}
\hline & & \multicolumn{3}{c}{$\boldsymbol{D}_{\boldsymbol{e}} \mathbf{3}$} \\
\cline { 3 - 5 } & & $\mathbf{0}$ & $\mathbf{1}$ & Total \\
\hline \multirow{3}{*}{$\mathrm{F} 1$} & $\mathbf{0}$ & 48 & 78 & 126 \\
\cline { 2 - 5 } & $\mathbf{1}$ & 84 & 40 & 124 \\
\cline { 2 - 5 } & Total & 132 & 118 & 250 \\
\hline
\end{tabular}

\subsection{Communication Channels for SM Awareness}

Communication channels preferred by the consumers' play a vital role in the information diffusion as well as raising consumers' awareness and addressing their concerns [42,52]. The respondents were asked a variety of questions to understand the communication channels in terms of electricity market in general and for SM diffusion in particular.

Figure 5, shows a comparison of three important variable sets:

- (i) sources of information regarding electricity (S1-S15),

- (ii) sources of information regarding SM (I31-I35), asked to only those who had knowledge about $\mathrm{SM}(\mathrm{K}=1, \mathrm{~N} 1=250)$,

- $\quad$ (iii) channels (Q21-Q35) they would prefer to use, to get more information about SM (Q1 = 1, $\mathrm{N} 2=275)$.

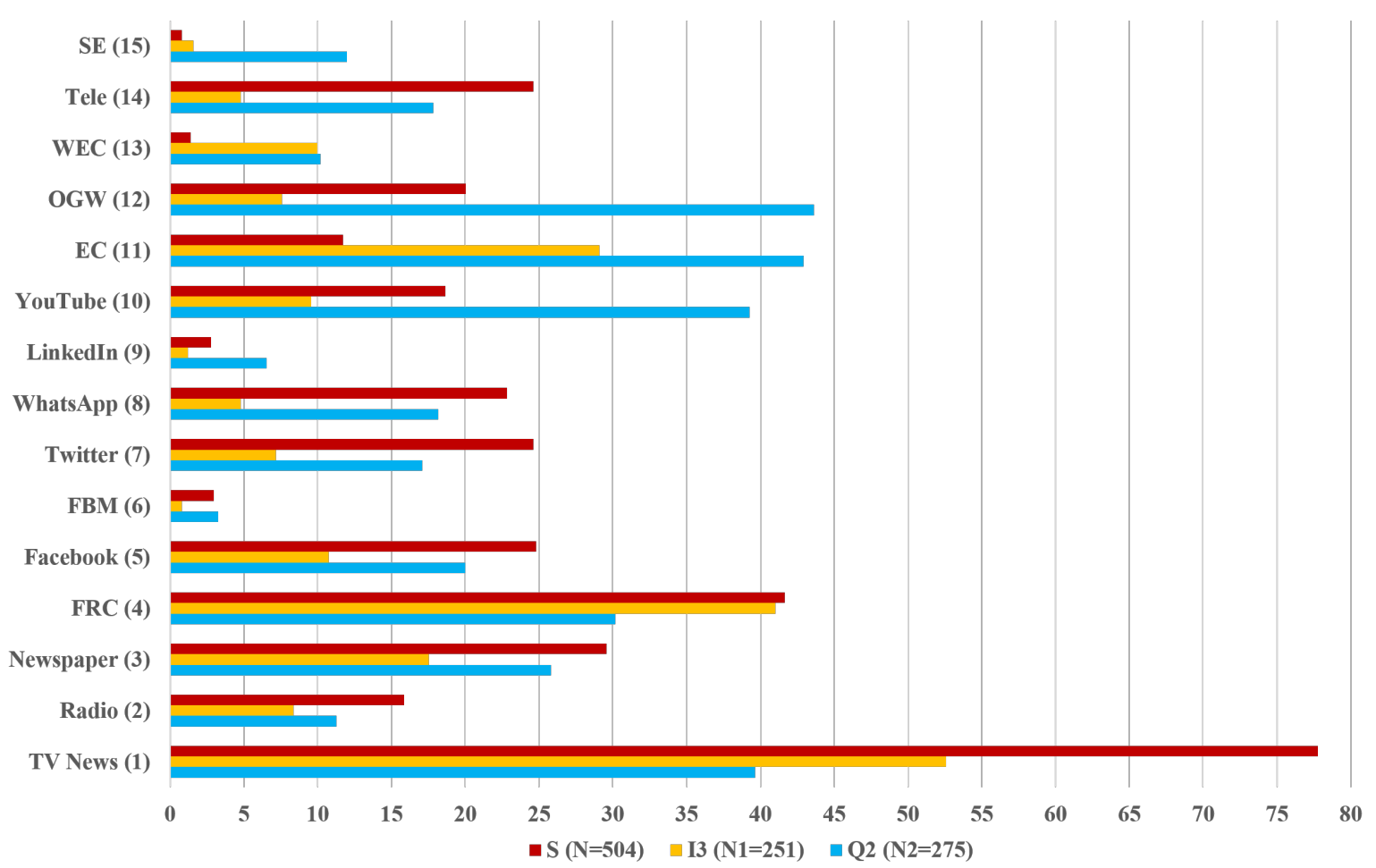

Figure 5. Sources of information regarding electricity (S), regarding SM (I3) and sources on which users would like to search for more information regarding SM (Q2). Note: S1-S15 correspond to the blue bars 1-15 respectively, I31-I45 correspond to yellow bars 1-15 respectively and Q21-Q35 correspond to red bars 1-15 respectively. (FRC: Friends, Relatives, Colleagues, FBM: Facebook Messenger, EC: Energy Companies, OGW: Official government websites, WEC: Workshops/Educational Campaigns, Tele: Telephone/SMS, SE: Search Engine).

From Figure 5, it can be seen that the most common source of information regarding electricity market in general as well as SM in particular was TV News, followed by the social peers such as friends, 
relatives and colleagues. Social media channels such as Facebook, Twitter, Whats App and YouTube were mentioned by $20 \%$ to $25 \%$ of respondents as sources from where they got some information regarding the electricity markets, but the same sources were less popular to get information about SM. Nearly $30 \%$ of the respondents who knew about SM mentioned energy companies as one of the source of information regarding SM, but the numbers dropped to $10 \%$ for the official government websites. Several respondents ( 76 out of 250 , for $\mathrm{K} 1=1$ ) indicated that they searched for information about SM (I1), but surprisingly only 2 of them indicated a government website to be the source of information regarding SM. Overall the number of respondents who indicated search engines as a source SM were less than $3 \%$.

At the end of the questionnaire, we asked all the respondents if they would try to get more information regarding SM (Q1) after participating in this study. N2 $=275$ respondents who said 'Yes' to Q1, were asked about the channels they would prefer to use for searching the information regarding SM (Q21-Q35). Computing the aggregate answer of Q21-Q35 for each respondent, we found that for the whole sample, the mean equals $3.3782(\mathrm{SD}=2.3527)$.

Despite the fact that we conducted this study among social media users, we can clearly see from the mean and standard deviation of the aggregate answers, as well as from the graph, that the respondents' choice of communication channels is wide and not just restricted to social media channels. In fact the conventional communication channels such as official government websites, energy companies themselves, TV news and social peers were amongst the most common choices. YouTube was the most common among social media channels with almost $40 \%$ of respondents indicating it as their choice, followed by Facebook, Twitter and WhatsApp. These social media channels are also among the top used platforms of the respondents in this study as well as for Turkey (see Figure 2). Although search engines were chosen by only $12 \%$ of the respondents who were in the category of $Q 1=1$, they have a major role to play, in order to make the content from the energy companies as well as government websites reachable for the consumers.

\subsection{Modeling of Knowledge about SM among Consumers and Discussion}

In order to evaluate the impact of different variables on the knowledge regarding SM (K1), a binary logistic regression model was used. This model reveals the statistically significant variables which influence the knowledge about SM among the consumers. In the regression analysis, only the variables corresponding to questions asked to all of the respondents $(\mathrm{N}=518)$ were considered. The detailed description of these variables can be seen in Table A1 (Appendix A). In the model, first a binary variable $Y_{i}$ is constructed. $Y_{i}$ takes value one when an i-th individual responds positively to K1 $(\mathrm{K} 1=1)$ and zero when a respondent declares not to know what an SM is $(\mathrm{K} 1=0)$. Thereafter the probability of consumers having knowledge about $\mathrm{SM}(\mathrm{K} 1=1)$ is assumed to be dependent on a set of variables $X_{i}$, which includes a constant and all the variables shown in group A of Table A1 (Appendix A). A general description of the logistic regression model is given in the Equation (1) below,

$$
\operatorname{Prob}\left(Y_{i}=1\right)=\frac{e^{x_{i} \beta}}{\left(1+e^{x_{i} \beta}\right)}
$$

where $\beta$ is a vector of the model coefficients and $X_{i}$ stands for a vector of the explanatory variables. The aim of the model is to describe the probability of having knowledge what SM is with a set of the explanatory variables.

The results of the model are presented in Table A2 (Appendix A), which shows that are many insignificant variables. To eliminate the insignificant variables we carried out a sequential elimination of variables using two-sided alpha $=0.05$ (similar to [65]) using the Gretl program. In this process, the variable having the highest $p$-value was omitted step by step until no remaining variable had a $p$-value greater than the cutoff (which was 0.05 in this case). The final model obtained after the elimination is shown in Table 8. 
Table 8. Results of the final Logit regression model for dependent variable: K1 (standard errors based on Hessian) for determination of $Y_{i}$.

\begin{tabular}{cccccc}
\hline Variable & Coefficient & Std. Error & $\mathbf{z}$ & Marginal Effect & $p$-Value \\
\hline const & -3.423 & 0.642 & -5.335 & & 0.000 \\
D2 & 0.371 & 0.087 & 4.285 & 0.093 & 0.000 \\
D10 & 0.264 & 0.111 & 2.381 & 0.066 & 0.017 \\
S01 & 0.481 & 0.209 & 2.297 & 0.120 & 0.022 \\
S03 & 0.613 & 0.256 & 2.393 & 0.151 & 0.017 \\
S1 & -0.517 & 0.242 & -2.132 & -0.128 & 0.033 \\
S12 & 0.586 & 0.258 & 2.269 & 0.144 & 0.023 \\
A34 & 0.580 & 0.209 & 2.775 & 0.144 & 0.006 \\
A35 & 0.892 & 0.233 & 3.834 & 0.217 & 0.000 \\
De6 & 0.550 & 0.238 & 2.314 & 0.136 & 0.021 \\
De7 & -0.835 & 0.262 & -3.186 & -0.206 & 0.001 \\
De8 & 1.112 & 0.250 & 4.441 & 0.271 & 0.000 \\
\hline
\end{tabular}

Mean dependent var 0.496032; S.D. dependent var 0.500481; McFadden $R^{2} 0.161733$; Adjusted $R^{2}$ 0.127382; Log-likelihood -292.8319; Akaike criterion 609.6639; Schwarz criterion 660.3348; Hannan-Quinn 629.5403.

Results of the Logit model, detailed in Table 8, show that the knowledge regarding SM is positively related with the following variables: age (D2), area of residence (D10), usage of Facebook (S01), usage of LinkedIn (S03), government website as source for information regarding electricity (S12), attitude towards investing in energy saving appliances (A34), attitude towards monitoring energy consumption in household (A35), acceptance of SM if it was a free upgrade (De6) and acceptance of SM if friends/relatives/neighbor installs it at their house $\left(D_{e} 8\right)$. This indicates a stepping up of the age group by 1 (for example from 25-35 to 36-45), while leaving all the other explanatory variables unchanged, there is a $9.3 \%$ higher probability of the consumers having knowledge about SM. Similarly there is a $6.6 \%$ more probability of consumers living in cities with higher population. In case of variables $\mathrm{S} 01, \mathrm{~S} 03, \mathrm{~S} 12, \mathrm{~A} 34, \mathrm{~A} 35, D_{e} 6$ and $D_{e} 7$, changing the individual negative responses to positive (while keeping all other explanatory variables unchanged) increases the probability of having knowledge about SM by 12\%, 15.1\%, 14.4\%, 14.4\%, 21.7\%, 13.6\% and $27.1 \%$, respectively. Two variables, TV channels as a source of information regarding electricity (S1) and acceptance of SM if one of the friends/relatives/neighbors recommends it $\left(D_{e} 7\right)$ influences the knowledge in the opposite way. Changing the responses of these variables individually to positive, while keeping all the other explanatory variables unaltered, decreases the likelihood of having knowledge regarding SM by $12.8 \%$ and $20.6 \%$, respectively. The prediction capabilities of the final Logit model is shown in Table 9, which shows that $69.25 \%$ of the responses were correctly predicted by the model.

Table 9. Prediction capabilities of the final Logit model.

\begin{tabular}{ccccc}
\hline & \multicolumn{3}{c}{ Predicted } & \multirow{2}{*}{ \% Correct } \\
\cline { 2 - 4 }$Y_{i}=\mathbf{0}$ & $Y_{\boldsymbol{i}}=\mathbf{1}$ & \\
\hline \multirow{2}{*}{ Observed } & $Y_{i}=0$ & 175 & 79 & $68.9 \%$ \\
\cline { 2 - 4 } & $Y_{i}=1$ & 76 & 174 & $69.6 \%$ \\
\hline \multicolumn{3}{c}{ Overall Percentage } & $69.25 \%$ \\
\hline
\end{tabular}

The final model appropriately fits the data, as the the Hosmer and Lemeshow goodness-of-fit is greater than 0.05 and the value of joint signifiance test is Chi-Square $=112.997$ with $p$-value $=0.000$. Final Logit model for is represented by Equation (2)

$$
\begin{aligned}
\operatorname{logit}(\text { Prob })=\log \frac{\text { Prob }}{(1-\text { Prob })}= & -3.423+0.371(D 2)+0.264(D 10)+0.481(S 01)+0.613(S 03)+0.586(S 12) \\
& +0.580(A 34)+0.892(A 35)+0.550(D e 6)+1.112(D e 8)-0.517(S 1)-0.835(D e 7)
\end{aligned}
$$




\section{Conclusions, Discussion and Recommendations}

\subsection{Conclusions and Discussion}

Turkey is facing growing demand for electricity. A trend, which is projected to continue in the coming years. Increasing the energy efficiency of the transmission grids, by upgrading to SG, is one of the feasible solutions that has been looked upon by the Turkish government, apart from moving towards renewables. A national rollout of SM has been initiated with CLK Enerji, Turkey's largest electricity distribution and retain group, undertaking the replacement of current electricity meters with SM in 11 provinces. The consumers' role is vital for the success of this technological upgrade. Studies in the literature indicate that enabling consumers the access to the information about their electricity consumption is not enough to guarantee benefits such as energy and money saving. The savings can be possible only if the consumers are willing to accept SM together with SMP, and engage in monitoring their usage of energy. Complete knowledge about SM, its features and benefits, are more likely to draw acceptance and engagement from the consumers. To reach out to consumers and disseminate the knowledge about SM, a range of communication channels would have to be used, as different groups of consumer prefer different communication channels. Our study addresses both these factors, determinants of knowledge regarding SM and the communication channels preferred by the consumers in Turkey.

\subsection{Determinants of Knowledge about SM}

Our study shows that consumers' knowledge about SM increases with age. Knowledge about SM was found to be higher among the aged consumers as compared to the young ones, who according to the literature are more tech-savvy, also referred to as early adopters of technology and more active on social media. This shows that the dissemination of information regarding SM is not adequate on social media platforms as a large majority of users on social media are of younger age groups. At the same time consumers active on social media platforms, like Facebook and LinkedIn, were more likely to have knowledge about SM, as compared to those who were not active on them. These young social media users can act, as so called influencers, to facilitate the propagation of information regarding SM enhancing the outcomes of the dissemination campaigns. Moreover, consumers who rely on government websites as the source of information for electricity are more likely to have knowledge about SM whereas those relying on TV news are found to be less probable to have knowledge. People, with a more pro-environmental attitude, such as a willingness to invest more for energy saving appliances and monitoring energy consumption were also found to be more probable to have knowledge about SM. Finally, the knowledge of what an SM is also correlates positively with the consumers' willingness to install SM if the upgrade is for free and if their peers have already installed SM. It is interesting to point out that the social influence has an important role to play for the acceptance of SM in cases where the consumers do not have knowledge about SM. This is evident through the negative correlation of the knowledge about SM with the willingness to accept SM if one of the friends, relatives or neighbors recommends it. The fact that the level of education (D4) was not significant for the knowledge about SM points out to the lack of attention in the educational curriculum regarding the socio-economic aspects of SM. For older age groups, above 25, the insignificance of the educational level for knowledge about SM can be justifiable, as when they would have been in school or in a higher educational institution, SM was not a popular concept. But, younger respondents were still going through the educational system when SM became a popular concept over a decade ago. Hence there is a need for the educational system, in Turkey, to address SM and related topics for the younger generation.

\subsection{Communication Channels}

Our study, conducted among social media users, shows that using a wide spectrum of communication channels is quite important. For instance "TV News" was found to be the top source 
of information regarding electricity among the consumers. But, at the same time it has a negative relation with knowledge about $\mathrm{SM}$, which indicates that consumers who rely more on TV news for information regarding electricity are not receiving knowledge about SM through it. The preferences regarding the communication channels to receive more information regarding SM also shows wide range of choices of both conventional and digital platforms including social media. Due to the high importance of social influence in acceptance of SM, social media platforms would be highly effective to create snowball effect for spreading knowledge about SM.

\subsection{Recommendations for Social Media Management to Enhance Consumer Acceptance of SM}

Based on the obtained results we recommend that the following steps would aid in enhancing consumer knowledge and acceptance of SM:

- A huge number of consumers are missing the primary information about SM, which requires an effective awareness campaign. Although there are some media outlets who have published articles about the SM rollout, it has yet to reach critical mass. Energy companies have posted content regarding SM on their websites, but there is a need to reach out to consumers through various communication channels, especially social media, disseminating the published information. It would be of great value to initially target the social media users in Turkey, as they are in considerable numbers and provide an opportunity to create a snowball effect for positive e-word of mouth. Initiating small campaigns through local influencers, user stories, use cases, the benefits of SM and especially addressing the fears/concerns discussed in Section 4.7 would prove to be effective.

- In continuation with the previous point, it would be valuable to create online social communities which would facilitate discussion and interaction among the consumer regarding the use of SM. In the study we found that social influence can play a role in increasing the acceptance of SM among consumers. Moreover, such online social communities also provide an opportunity for the energy companies to create gamification campaigns which would engage the consumers further.

- In some cases we found that lack of proper knowledge or incomplete knowledge was one of the reasons for false fears, which requires swift rectification. Creating a standard information package for users, based on their preference of different types of communication channels, with information about SM basics at first and then the advanced features, is recommended. Consumers active on different communication channels are in sync with the type of content propagated through that communication channel. For instance, users preferring to get information through videos are more active on YouTube as compared to a text blog and vice-versa in case of users preferring to read text instead of watching videos. An information package for different channels would ensure that consumers with different attitudes towards obtaining information would be addressed. Based on the results of this study as well as the previous one [34], the information containing the following topics is recommended:

- Basic knowledge about SM, its functions, myths, long term and short term impacts, potential benefits: financial, social, environmental and economic ones.

- Usefulness of SM: monitoring of energy use, ability to remotely control energy usage and getting real time information.

- Addressing fears and concerns: security of personal data, safety features, health issues, accuracy in billing and others.

- Involving the social factors: interactions through experts with the support of social influencers and current users of SM, consumer feedbacks and experiences or assurances.

\section{Limitations of the Study and Future Work}

The present study has certain limitation, although vigorous efforts were made to broaden the scope of research, which point to future research avenues. The analyzed sample introduces limitations in 
terms of geographical context and the non-random sampling methods used. Hence it is recommended to replicate this study in different samples, for instance independent studies in different regions of Turkey, to obtain a more specific regional understanding. Respondents for this study were located from almost all regions of Turkey, but we did not take into consideration the regional effect on the responses. This can prove to be important, as Turkey's transition plan includes getting region specific requirements. Secondly, the study can be replicated in other countries where SM rollout is at an initial phase or is about to commence.

This particular study is a part of our larger project, under which similar studies have already been conducted in five countries and we also aim to carry out further similar studies in other countries. We also feel that testing the effectiveness of recommendations for SM diffusion, outlined in this study, could be one of the future steps. The study also lays grounds for further research on creation and testing of online social communication for diffusion of SM knowledge. Similar studies for understanding consumer attitudes and opinions for other innovations/smart technologies can also be undertaken.

Author Contributions: Y.C. conceived and designed the survey; A.K.-P. reviewed the design of the survey; B.O. carried out translations (English-Turkish and vice-versa) of the questionnaire; Y.C. created and managed the online questionnaire; B.O. collected the data through the online questionnaire; Y.C. analyzed the data; A.K.-P. and B.O. reviewed the literature; A.K.-P. and Y.C. drafted and edited the paper; A.K.-P. and Y.C. revised the paper. All authors have read and agreed to the published version of the manuscript.

Funding: This work was supported by the Faculty of Computer Science and Management, Wrocław University of Science and Technology from funds of the Ministry of Science and Higher Education subsidy in the part devoted to conducting research activities in 2019 and by the National Science Center (NCN, Polska) by grant no. 2016/23/B/HS4/00650.

Acknowledgments: We would like to thank the editors and reviewers for their constructive remarks and suggestions. We want also to thank Marta Pytel for English language proofreading.

Conflicts of Interest: The authors declare no conflict of interest.

\section{Abbreviations}

The following abbreviations are used in this manuscript:

SG smart grids

SM electricity smart meters

SMP smart metering platform (SM information systems)

TL Turkish Lira

DSM/DR Demand Side Management and Demand Response tools

DoI Diffusion of innovation model

\section{Appendix A}

Table A1. Definitions of the variables, coding and description $(\mathrm{N}=504)$.

\begin{tabular}{|l|l|l|}
\hline Variable & Code & Description \\
\hline \multicolumn{2}{|c|}{ Group A (Variables of Phase 1) } \\
\hline Demographics & $\begin{array}{l}\text { D1-D10, } \\
\text { D81 }\end{array}$ & \\
\hline Gender & D1 & 1 = male, 2 = female \\
\hline Age & D2 & 6 categories (ordinal) \\
\hline Relationship status & D3 & 5 categories (nominal) \\
\hline Highest Educational Qualification & D4 & 6 categories (ordinal) \\
\hline Occupation/Employment & D5 & 6 categories (nominal) \\
\hline Monthly Household Income (in TL per month) & D6 & 12 categories (ordinal) \\
\hline Range of electricity bill (in TL per month) & D7 & 5 categories (ordinal) \\
\hline Total members in the household & D8 & 6 categories (ordinal) \\
\hline Number of children & D81 & 5 categories (ordinal) \\
\hline Type of house & D9 & 4 categories (nominal) \\
\hline Place of living & D10 & 5 categories (ordinal) \\
\hline
\end{tabular}


Table A1. Cont.

\begin{tabular}{|c|c|c|}
\hline Variable & Code & Description \\
\hline Belongings of smart devices and personal assets) & B1-B7 & \\
\hline House & B1 & \multirow[t]{7}{*}{$\begin{array}{l}\text { (2) yes } /(1) \text { no, but I plan to buy it within } \\
\text { one year } /(0) \text { no, and I do not plan to buy } \\
\text { it. }\end{array}$} \\
\hline Flat or Apartment & B2 & \\
\hline Laptop & B3 & \\
\hline Wifi/Internet connection home & B4 & \\
\hline Home appliances that can connect to the internet & B5 & \\
\hline Electric vehicle & B6 & \\
\hline $\begin{array}{l}\text { Any smart technologies that enable monitoring and } \\
\text { control of energy consumption at house }\end{array}$ & B7 & \\
\hline Behaviour towards buying new technology & A1-A2 & \multirow{3}{*}{$\begin{array}{l}\text { (1) I buy once in more than three } \\
\text { years/(2) I buy once every three } \\
\text { years/(3) I buy once every two years/(4) } \\
\text { I buy once in a year/(5) I buy twice per } \\
\text { year/(6) I buy thrice or more per year }\end{array}$} \\
\hline $\begin{array}{l}\text { Upgrading electronic home appliances with new } \\
\text { versions }\end{array}$ & A1 & \\
\hline Buying new mobile phone to get latest technology & A2 & \\
\hline $\begin{array}{l}\text { Behaviour towards environment and energy } \\
\text { saving }\end{array}$ & A31-A39 & \\
\hline $\begin{array}{l}\text { Followed any organization(s) or profile(s) on social } \\
\text { media promoting energy saving }\end{array}$ & A31 & \multirow{9}{*}{ (1) yes /(0) no } \\
\hline $\begin{array}{l}\text { Performed internet search about eco-friendly ways } \\
\text { of living }\end{array}$ & A32 & \\
\hline Re-used grocery bags & A33 & \\
\hline $\begin{array}{l}\text { Invested in energy saving appliance(s) for } \\
\text { household }\end{array}$ & A34 & \\
\hline $\begin{array}{l}\text { Regular monitored of energy consumption at } \\
\text { household }\end{array}$ & A35 & \\
\hline Segregated garbage & A36 & \\
\hline $\begin{array}{l}\text { Ever returned home to check whether all home } \\
\text { appliance(s) or light(s) are turned off }\end{array}$ & A37 & \\
\hline $\begin{array}{l}\text { Ever paid more for buying more energy efficient } \\
\text { appliance }\end{array}$ & A38 & \\
\hline $\begin{array}{l}\text { Ever picked up trash left by somebody elese, while } \\
\text { being outdoor }\end{array}$ & A39 & \\
\hline $\begin{array}{l}\text { Renewable energy sources installed at the } \\
\text { household }\end{array}$ & R1 & (1) yes /(0) no \\
\hline Social media platforms commonly used & S01-S08 & \\
\hline Facebook & S01 & \multirow{8}{*}{ (1) yes $/(0)$ no } \\
\hline Facebook Messenger & S02 & \\
\hline LinkedIn & S02 & \\
\hline Twitter & S03 & \\
\hline WhatsApp & S04 & \\
\hline Youtube & S05 & \\
\hline Instagram & S02 & \\
\hline Snap Chat & S02 & \\
\hline $\begin{array}{l}\text { Source of information regarding electricity } \\
\text { (prices, new offers, etc.) }\end{array}$ & S1-S15 & $\begin{array}{l}\text { (1) Yes/(0) No (Note: variables are listed in } \\
\text { the table notes) }\end{array}$ \\
\hline Preferences regarding SM platforms & P1-P4 & \\
\hline $\begin{array}{l}\text { Getting more details on electricity usage is } \\
\text { desirable }\end{array}$ & P1 & \multirow{4}{*}{ (1) yes $/(0)$ no } \\
\hline $\begin{array}{l}\text { Getting real time information of electricity usage } \\
\text { would be useful }\end{array}$ & P2 & \\
\hline $\begin{array}{l}\text { Prefer to be able to remotely turn on or off the } \\
\text { electricity supply }\end{array}$ & P3 & \\
\hline $\begin{array}{l}\text { Prefer to have fluctuating unit rates of electricity } \\
\text { usage }\end{array}$ & P4 & \\
\hline
\end{tabular}


Table A1. Cont.

\begin{tabular}{|c|c|c|}
\hline Variable & Code & Description \\
\hline Willingness to install SM & $\begin{array}{l}D_{e} 1-D_{e} 4 \\
D_{e} 6-D_{e} 8\end{array}$ & \\
\hline Willing if SM could help save money & $D_{e} 1$ & \multirow{7}{*}{ (1) yes $/(0)$ no } \\
\hline $\begin{array}{l}\text { Willing if SM could help save money, but possible } \\
\text { have adverse effect on health }\end{array}$ & $D_{e} 2$ & \\
\hline $\begin{array}{l}\text { Willing if SM could have save money, but energy } \\
\text { companies would have access to electricity usage } \\
\text { data }\end{array}$ & $D_{e} 3$ & \\
\hline $\begin{array}{l}\text { Willing if company representative visits home and } \\
\text { expalin all details }\end{array}$ & $D_{e} 4$ & \\
\hline Willing to install if upgrade to SM is free & $D_{e} 6$ & \\
\hline $\begin{array}{l}\text { Willing to install if } \quad \text { one of the } \\
\text { friends/relatives/neighbours }\end{array}$ & $D_{e} 7$ & \\
\hline 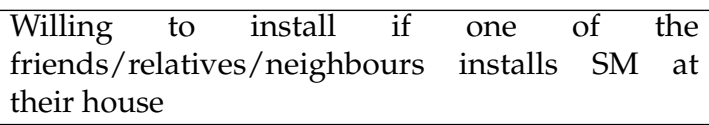 & $D_{e} 8$ & \\
\hline Concerns about SM usage & F1,F4 & \\
\hline Data privacy concerns & F1 & \multirow{2}{*}{ (1) yes /(0) no } \\
\hline $\begin{array}{l}\text { Fluctuations in unit rate of electricity would cause } \\
\text { additional stress }\end{array}$ & F4 & \\
\hline \multicolumn{3}{|c|}{ Group B (Conditional Variable for Phase 2) } \\
\hline Knows what is a SM & K1 & (1) yes /(0) no \\
\hline Group B (Variable & of Phase 2-For & $K 1=1)$ \\
\hline Knowledge about SM & $\mathrm{K} 2-\mathrm{K} 4$ & \\
\hline Has SM installed at home & $\mathrm{K} 2$ & \multirow{4}{*}{ (1) yes $/(0)$ no } \\
\hline In process of installing SM at home & K3 & \\
\hline Plans to install SM at home & K4 & \\
\hline Source of information regarding SM & $\begin{array}{ll}\text { I1, I2, } \\
\text { I31-I45 }\end{array}$ & \\
\hline Internet, other than search engine & I1 & \multirow{3}{*}{ (1) yes $/(0)$ no } \\
\hline Government's rollout programme & $\mathrm{I} 2$ & \\
\hline Other sources (variables are listed in the table notes) & I31-I45 & \\
\hline Social influence & W1 & (1) yes/(0) no \\
\hline $\begin{array}{l}\text { Willing to install SM even if payment is required } \\
\text { for upgrade }\end{array}$ & $D_{e} 5$ & \multirow[t]{2}{*}{ (1) yes/(0) no } \\
\hline $\begin{array}{l}\text { Preferences regarding the role of the government } \\
\text { in SM enrollment }\end{array}$ & G1-G3 & \\
\hline $\begin{array}{l}\text { Government should make it mandatory for all to } \\
\text { have SM }\end{array}$ & G1 & \multirow[t]{3}{*}{ (1) yes $/(0)$ no } \\
\hline $\begin{array}{l}\text { Government should give an option to decline } \\
\text { installation of SM }\end{array}$ & G2 & \\
\hline $\begin{array}{l}\text { Would protest if government makes it mandatory } \\
\text { to install SM }\end{array}$ & G3 & \\
\hline Concerns about SM usage & F2, F3 & \\
\hline Billing through SM could be inaccurate & F2 & \multirow{2}{*}{ (1) yes $/(0)$ no } \\
\hline SM could have adverse effects on health & F3 & \\
\hline $\begin{array}{l}\text { Willingness to have one's home to be equipped } \\
\text { with SM }\end{array}$ & $\mathbf{X 1}$ & (1) yes/(0) no \\
\hline \multicolumn{3}{|c|}{ Group C (Conditional Variable for Phase 3) } \\
\hline $\begin{array}{l}\text { Willingness to search or collect more information } \\
\text { regarding SM }\end{array}$ & Q1 & (1) yes/(0) no \\
\hline \multicolumn{3}{|c|}{ Group C (Variables of Phase 3-For Q1 = 1) } \\
\hline $\begin{array}{l}\text { Source of Information preferred to search or } \\
\text { collect more information regarding SM }\end{array}$ & Q21-Q35 & $\begin{array}{l}\text { (1) yes/(0) no (Note: variables are listed in } \\
\text { the table notes) }\end{array}$ \\
\hline
\end{tabular}

Note: TV News (S1, I31, Q21); Radio (S2, I32, Q22); Newspaper (S32, I33, Q23); Friends, relatives, colleagues (S4, I34, Q24); Facebook (S5, I35, Q25); Facebook Messenger (S6, I36, Q26); Twitter (S7, I37, Q27); WhatsApp (S8, I38, Q28); LinkedIn (S9, I39, Q29); YouTube (S10 I40, Q30); Energy Companies (S11, I41, Q31); Official government websites (S12, I42, Q32); Workshops/educational campaigns (S13, I43, Q33); Telephone/SMS (S14, I44, Q34); Search engines (S15, I45, Q35). 
Table A2. Results of initial Logit Regression Model for Dependent variable: K1 (Standard errors based on Hessian) for determination of $Y_{i}$.

\begin{tabular}{|c|c|c|c|c|}
\hline Variable & Coefficient & Std. Error & $\mathbf{z}$ & $p$-Value \\
\hline const & -4.34585 & 1.46679 & -2.963 & 0.0030 \\
\hline D1 & 0.0931032 & 0.255792 & 0.3640 & 0.7159 \\
\hline $\mathrm{D} 2$ & 0.267239 & 0.165476 & 1.615 & 0.1063 \\
\hline D3 & 0.279179 & 0.185745 & 1.503 & 0.1328 \\
\hline D4 & 0.0955307 & 0.175709 & 0.5437 & 0.5867 \\
\hline D5 & 0.0136375 & 0.0664223 & 0.2053 & 0.8373 \\
\hline D6 & 0.00488104 & 0.0727889 & 0.06706 & 0.9465 \\
\hline D7 & -0.0973837 & 0.170998 & -0.5695 & 0.5690 \\
\hline D8 & 0.109854 & 0.102405 & 1.073 & 0.2834 \\
\hline D81 & -0.0657327 & 0.191642 & -0.3430 & 0.7316 \\
\hline D9 & 0.0210567 & 0.197214 & 0.1068 & 0.9150 \\
\hline D10 & 0.310426 & 0.138547 & 2.241 & 0.0251 \\
\hline S01 & 0.579175 & 0.290663 & 1.993 & 0.0463 \\
\hline $\mathrm{S} 02$ & 0.0210224 & 0.333660 & 0.06301 & 0.9498 \\
\hline S03 & 0.680142 & 0.318111 & 2.138 & 0.0325 \\
\hline S04 & -0.525183 & 0.304589 & -1.724 & 0.0847 \\
\hline S05 & -0.234781 & 0.468434 & -0.5012 & 0.6162 \\
\hline S06 & -0.144067 & 0.293251 & -0.4913 & 0.6232 \\
\hline S07 & -0.111510 & 0.330682 & -0.3372 & 0.7360 \\
\hline S08 & 0.142987 & 0.344899 & 0.4146 & 0.6785 \\
\hline B1 & 0.0700210 & 0.153048 & 0.4575 & 0.6473 \\
\hline B2 & -0.0715037 & 0.136685 & -0.5231 & 0.6009 \\
\hline B3 & 0.183646 & 0.171654 & 1.070 & 0.2847 \\
\hline B4 & -0.0629511 & 0.243642 & -0.2584 & 0.7961 \\
\hline B5 & 0.248945 & 0.186826 & 1.332 & 0.1827 \\
\hline B6 & 0.212604 & 0.210233 & 1.011 & 0.3119 \\
\hline B7 & 0.127893 & 0.165379 & 0.7733 & 0.4393 \\
\hline S1 & -0.577253 & 0.274246 & -2.105 & 0.0353 \\
\hline S2 & 0.0121528 & 0.351380 & 0.03459 & 0.9724 \\
\hline S3 & 0.178391 & 0.273498 & 0.6523 & 0.5142 \\
\hline S4 & 0.0291626 & 0.245521 & 0.1188 & 0.9055 \\
\hline S5 & -0.0659728 & 0.329382 & -0.2003 & 0.8413 \\
\hline S6 & 0.201088 & 0.685628 & 0.2933 & 0.7693 \\
\hline S7 & 0.164173 & 0.325877 & 0.5038 & 0.6144 \\
\hline S8 & -0.542389 & 0.322082 & -1.684 & 0.0922 \\
\hline S9 & 1.13231 & 0.697245 & 1.624 & 0.1044 \\
\hline $\mathrm{S} 10$ & -0.0283239 & 0.332303 & -0.08524 & 0.9321 \\
\hline S11 & -0.0151670 & 0.360266 & -0.04210 & 0.9664 \\
\hline S12 & 0.521208 & 0.296452 & 1.758 & 0.0787 \\
\hline $\mathrm{S} 13$ & 0.249130 & 0.950570 & 0.2621 & 0.7933 \\
\hline S14 & 0.278293 & 0.283591 & 0.9813 & 0.3264 \\
\hline S15 & 0.784459 & 1.34753 & 0.5821 & 0.5605 \\
\hline A1 & -0.198726 & 0.156349 & -1.271 & 0.2037 \\
\hline $\mathrm{A} 2$ & 0.0856742 & 0.123348 & 0.6946 & 0.4873 \\
\hline A31 & 0.300665 & 0.274168 & 1.097 & 0.2728 \\
\hline A32 & -0.514857 & 0.269346 & -1.912 & 0.0559 \\
\hline A33 & -0.171275 & 0.370348 & -0.4625 & 0.6437 \\
\hline A34 & 0.696631 & 0.249602 & 2.791 & 0.0053 \\
\hline A35 & 1.10592 & 0.278474 & 3.971 & 0.0001 \\
\hline A36 & 0.401872 & 0.254818 & 1.577 & 0.1148 \\
\hline A37 & -0.231040 & 0.292856 & -0.7889 & 0.4302 \\
\hline A38 & -0.222811 & 0.258386 & -0.8623 & 0.3885 \\
\hline A39 & -0.293846 & 0.333667 & -0.8807 & 0.3785 \\
\hline R1 & 0.216237 & 0.285061 & 0.7586 & 0.4481 \\
\hline $\mathrm{P} 1$ & 0.303739 & 0.308630 & 0.9842 & 0.3250 \\
\hline P2 & -0.390941 & 0.320582 & -1.219 & 0.2227 \\
\hline P3 & 0.0158712 & 0.335997 & 0.04724 & 0.9623 \\
\hline P4 & 0.0849537 & 0.297580 & 0.2855 & 0.7753 \\
\hline
\end{tabular}


Table A2. Cont.

\begin{tabular}{ccccc}
\hline Variable & Coefficient & Std. Error & $\mathbf{z}$ & $\boldsymbol{p}$-Value \\
\hline F1 & 0.0296559 & 0.235794 & 0.1258 & 0.8999 \\
F4 & 0.190290 & 0.237482 & 0.8013 & 0.4230 \\
De1 & -0.436749 & 0.364867 & -1.197 & 0.2313 \\
De2 & -0.968640 & 0.447898 & -2.163 & 0.0306 \\
De3 & 0.306588 & 0.248226 & 1.235 & 0.2168 \\
De4 & 0.396967 & 0.283658 & 1.399 & 0.1617 \\
De6 & 0.591198 & 0.278186 & 2.125 & 0.0336 \\
De7 & -1.11000 & 0.308945 & -3.593 & 0.0003 \\
De8 & 1.33244 & 0.293184 & 4.545 & 0.0000 \\
Q1 & -0.189544 & 0.251113 & -0.7548 & 0.4504 \\
\hline
\end{tabular}

Mean dependent var 0.496032; S.D. dependent var 0.500481; McFadden $R^{2} 0.217410$; Adjusted $R^{2} 0.022752$; Log-likelihood -273.3825; Akaike criterion 682.7650; Schwarz criterion 969.9002; Hannan-Quinn 795.3980.

\section{References}

1. Ellabban, O.; Abu-Rub, H. Smart grid customers' acceptance and engagement: An overview. Renew. Sustain. Energy Rev. 2016, 65, 1285-1298. [CrossRef]

2. Biresselioglu, M.E.; Nilsen, M.; Demir, M.H.; Royrvik, J.; Koksvik, G. Examining the barriers and motivators affecting european decision makers in the development of smart and green energy technologies. J. Clean. Prod. 2018, 198, 417-429. [CrossRef]

3. Crispim, J.; Braz, J.; Castro, R.; Esteves J. Smart grids in the eu with smart regulation: Experiences from the UK, Italy and Portugal. Util. Policy 2014, 31, 85-93. [CrossRef]

4. Zhou, S.; Brown, M.A. Smart meter deployment in Europe: A comparative case study on the impacts of national policy schemes. J. Clean. Prod. 2017, 144, 22-32. [CrossRef]

5. Sial, A.; Singh, A.; Mahanti, A. Detecting anomalous energy consumption using contextual analysis of smart meter data. Wirel. Netw. 2019. [CrossRef]

6. Thomson, W.; Mahanti, A.; Gong, M. Uploader Motivations and Consumer Dynamics in the One-Click File Hosting Ecosystem. In Proceedings of the 2018 IEEE International Conference on Communications, (ICC), Kansas City, MO, USA, 20-24 May 2018; doi:10.1109/ICC.2018.8422248. [CrossRef]

7. Gans, W.; Alberini, A.; Longo, A. Smart meter devices and the effect of feedback on residential electricity consumption: Evidence from a natural experiment in Northern Ireland. Energy Econ. 2013, 36, 729-743. [CrossRef]

8. Beemsterboer, S.; Sengers, F.; Verbong, G.P.J. Smart grids or smart users? involving users in developing a low carbon electricity economy. Energy Policy 2013, 52, 115-125.

9. Burchell, K.; Rettie, R.; Roberts, T.C. Householder engagement with energy consumption feedback: The role of community action and communications. Energy Policy 2016, 88, 178-186. [CrossRef]

10. Schleich, J.; Faure, C.; Klobasa, M. Persistence of the effects of providing feedback alongside smart metering devices on household electricity demand. Energy Policy 2017, 107, 225-233. [CrossRef]

11. Krishnamutri, T.; Schwartz, D.; Davis, A.; Fischoff, B.; de Bruin, W.B.; Lave, L.; Wang, J. Preparing for smart grid technologies: A behavioral decision research approach to understanding consumer expectations about smart meters. Energy Policy 2012, 41, 790-797. [CrossRef]

12. Kabalci, Y. A survey on smart metering and smart grid communication. Renew. Sustain. Energy Rev. 2016, 57, 302-318. [CrossRef]

13. Avancini, D.B.; Rodriques, J.J.P.C.; Martins, S.G.B.; Rabelo, R.A.L.; Al-Mahtadi, J.; Solic, P. Energy meters evolution in smart grids: A review. J. Clean. Prod. 2019, 217, 702-715. [CrossRef]

14. Wolsink, M. Distributed generation for sustainable energy as a common pool resource: Social acceptance in rural setting of smart (micro-) grid configurations. In New Rural Spaces: Towards Renewable Energies, Multifunctional Farming, and Sustainable Tourism; Frantal, B., Martiant, S., Eds.; Publisher: Brno, Czech Republic, 2014; pp. 36-47.

15. Chen, C.; Xu, X.; Arpan, L. Between the technology acceptance model and sustainable energy technology acceptance model: Investigating smart meter acceptance in the United States. Energy Res. Soc. Sci. 2017, 25, 93-104. 
16. Kahma, N.; Matschoss, K. The rejection of innovations? rethinking technology diffusion and the non-use of smart energy services in Finland. Energy Resour. Soc. Sci. 2017, 34, 27-36. [CrossRef]

17. Kowalska-Pyzalska, A.; Byrka, K. Determinants of the willingness to energy monitoring by residential consumers: A case study in the city of Wroclaw in Poland. Energies 2019, 12, 907. [CrossRef]

18. Nachreiner, M.; Mack, B.; Matthies, E.; Tampe-Mai, K. An analysis of smart metering information systems: A psychological model of self-regulated behavioral change. Energy Res. Soc. Sci. 2015, 9, 85-97. [CrossRef]

19. Droge, C.; Stanko, M.A.; Pollitte, W.A. Lead users and early adopters on the web: The role of new technology product blogs. J. Prod. Innov. Manag. 2010, 27, 66-82. [CrossRef]

20. Alsabbagh, M. Public perception toward residential solar panels in Bahrain. Energy Rep. 2019, 5, $253-261$. [CrossRef]

21. Sohn, K.; Kwon, O. Technology acceptance theories and factors influencing artificial intelligence-based intelligent products. Telemat. Inform. 2020, 47, 101324. [CrossRef]

22. Park, C.; Kim, H.; Yong, T. Dynamic characteristics of smart grid technology acceptance. Energy Procedia 2017, 128, 187-193. [CrossRef]

23. Mani, S.; Dhingra, T. Diffusion of innovation model of consumer behaviour-Ideas to accelerate adoption of renewable energy sources by consumer communities in India. Renew. Energy 2012, 39, 162-165. [CrossRef]

24. Kowalska-Pyzalska, A. Do consumers want to pay for green electricity? A case study from Poland. Sustainability 2019, 11, 1310. [CrossRef]

25. Ozaki, R. Adopting sustainable innovation: What makes consumers sign up to green electricity? Bus. Strategy Environ. 2011, 20, 1-17. [CrossRef]

26. Gerpott, T.J.; Mahmudova, I. Determinants of green electricity adoption among residential customers in Germany. Int. J. Consum. Stud. 2010, 34, 464-473. [CrossRef]

27. Rogers, E.M. Diffusion of Innovations, 5th ed.; Free Press: New York, NY, USA, 2003. [CrossRef]

28. Peres, R.; Muller, E.; Mahajan, V. Innovation diffusion and new product growth models: A critical review and research directions. Int. J. Res. Mark. 2010, 27, 91-106.

29. Kowalska-Pyzalska, A. An empirical analysis of green electricity adoption among residential consumers in Poland. Sustainability 2018, 10, 2281.

30. Iqtiyanillham, N.; Hasanuzzaman, M.; Hosenuzzaman, M. European smart grid prospects, policies, and challenges. Renew. Sustain. Energy Rev. 2017, 67, 776-790.

31. Park, C.K.; Kim, H.J.; Kim, Y.S. A Study of Factors Enhancing Smart Grid Consumer Engagement. Energy Policy 2014, 7, 211-218.

32. Bugden, D.; Stedman, R. A synthetic view of acceptance and engagement with smart meters in the United States. Energy Res. Soc. Sci. 2019, 47, 137-145.

33. AFMERCADOS EMI. Turkey Smart Grid 2023 Vision and Strategy Roadmap Summary Report. 2014. Available online: yearwww.smartgridturkey.org (accessed on 10 November 2019). [CrossRef]

34. Chawla Y.; Kowalska-Pyzalska A. Public awareness and consumer acceptance of smart meters among Polish social media users. Energies 2019, 12, 2759. [CrossRef]

35. Claudy, M.C.; Michelsen, C.; O’Driscoll, A.; Mullen, M.R. Consumer awareness in the adoption of microgeneration technologies. An empirical investigation in the Republic of Ireland. Renew. Sustain. Energy Rev. 2010, 14, 2154-2160. [CrossRef]

36. Chawla, Y.; Kowalska-Pyzalska, A.; Skowronska-Szmer A. Perspectives of Smart Meters' Roll-out in India: An Empirical Analysis of Consumers' Awareness and Preferences; Working Paper, Hugo Steinhaus Center, Wroclaw University of Technology HSC Research Reports HSC/19/03; 2020. Available online: https://ideas/repec/org/ p/wuu/wpaper/hsc1903.html (accessed on 7 January 2020). [CrossRef]

37. Buchanan, K.; Russo, R.; Anderson B. Feeding back about eco-feedback: How do consumers use and respond to energy monitors? Energy Policy 2014, 73, 138-146. [CrossRef]

38. Fisher, C. Feedback on household electricity consumption: A tool for saving energy? Energy Effic. 2008, 1, 79-104.

39. Good, N.; Ellis, K.A.; Mancarella, P. Review and classification of barriers and enablers of demand response in the smart grid. Renew. Sustain. Energy Rev. 2017, 16, 57-72. [CrossRef]

40. Foulds, C.; Robison, R.A.V.; Macrorie, R. Energy monitoring as a practice: Investigating use of the imeasure online energy feedback tool. Energy Policy 2017, 104, 194-202. [CrossRef] 
41. Ma, G.; Lin, J.; Li, N. Longitudinal assessment of the behavior-changing effect of app-based eco-feedback in residential buildings. Energy Build. 2018, 159, 486-494.

42. McMichael, M.; Shipworth, D. The value of social networks in the diffusion of energy-efficiency innovations in UK households. Energy Policy 2013, 53, 159-168. [CrossRef]

43. Chawla, Y.; Kowalska-Pyzalska, A.; Silveira, P. Marketing and Communication Channels for Diffusion of Smart Meters in Portugal; Working Paper (No. HSC/19/05); Hugo Steinhaus Center, Wroclaw University of Technology. Available online: https://ideas/repec/org/p/wuu/wpaper/hsc1905.html (accessed on 7 January 2020). [CrossRef]

44. Ravazi, R.; Gharipour, A.; Fleury, M.; Ikpe-Justice, A. Occupancy Detection of Residential Buildings Using Smart Meter Data: A Large-Scale Study. Energy Build. 2019, 183, 195-208. [CrossRef]

45. Hess, D.J. Smart meters and public acceptance: Comparative analysis and governance implications. Heal. Risk Soc. 2014, 16, 243-258. [CrossRef]

46. Bigerna, S.; Bollino, C.A.; Micheli, S. Socio-economic acceptability for smart grid development-A comprehensive review. J. Clean. Prod. 2016, 6131, 399-409. [CrossRef]

47. Gerpott, T.J.; Paukert, M. Determinnants of willingness to pay for smart meters: An empirical analysis of household customers in Germany. Energy Policy 2013, 61, 483-495. [CrossRef]

48. Kowalska-Pyzalska, A. What makes consumers adopt to innovative energy sources in the energy market? A review of incentives and barriers. Renew. Sustain. Energy Rev. 2018, 82, 3570-3581.

49. Podgornik, A.; Sucic, B.; Blazic, B. Effects of customized consumption feedback on energy efficient behavior in low-income households. J. Clean. Prod. 2016, 130, 25-34.

50. Weron, T.; Kowalska-Pyzalska, A.; Weron, R. The role of educational trainings in the diffusion of smart metering platforms: An agent-based modeling approach. Phys. A Stat. Mech. Its Appl. 2018, 505, 591-600. [CrossRef]

51. Raimi, K.T.; Carrico, A.R. Understanding and beliefs about smart energy technology. Energy Res. Soc. Sci. 2016, 12, 68-74. [CrossRef]

52. Khan, M.Z.; Miankhel, A.K.; Nawaz, A. Information \& communication technology and 'individual': Prospects \& concerns. Glob. J. Comput. Sci. Technol. 2013, 13, 1-10

53. Ma, L.; Lee, C.S.; Goh, D.H.L. Understanding news sharing in social media: An explanation from the diffusion of innovation theory. Online Inf. Rev. 2014, 38, 598-615. [CrossRef]

54. Colak, I.; Bayindir, R.; Fulli, G.; Tekin, I.; Demirtas, K.; Covrig, C.-F. Smart grid opportunities and applications in Turkey. Renew. Sustain. Energy Rev. 2014, 33, 344-352. [CrossRef]

55. Elma O.; Selamoğullari, U.S. An overview of demand response applications under smart grid concept. In Proceedings of the 4th International Conference on Clectrical and Electronic Engineering (ICEEE), Ankara, Turkey, 8-10 April 2017; pp. 104-107. [CrossRef]

56. Atasoy, T.; Akinc, H.E.; Erol, E.; Ercin, O.; Gurec, O.; Benli O. Challenges and opportunities towards smart grid in Turkey: Distribution system operator perspective. In Proceedings of the IEEE PES Innovative Smart Grid Technologies Rope, Istanbul, Turkey, 12-15 October 2014; pp. 1-6. [CrossRef]

57. Gungor, V.C.; Sahin, D.; Kocak, T.; Ergüt, S. Smart Grid Communications and Networking; Türk Telekom Technic Report, 11316-01; Türk Telekom: Altındağ, Turkey, 2011.

58. Demirci, T.; Kalaycıoglu, A.; Küçük, D.; Salor, Ö.; Güder, M.; Pakhuylu, S.; Atalık, T.; Inan, T.; Çadırcı, I.; Akkaya, Y.; et al. Nationwide real-time monitoring system for electrical quantities and power quality of the electricity transmission system. IET Gener. Transm. Distrib. 2011, 5, 540-550. [CrossRef]

59. Tumbaz, M.N.M.; Mogulkoc, H.T. Profiling energy efficiency tendency: A case for Turkish households. Energy Policy 2018, 119, 441-448. [CrossRef]

60. Malinen, S.; Ojala, J. Maintaining the instant connection-Social media practices of smartphone Users. In From Research to Practice in the Design of Cooperative Systems: Results and Open Challenges; Springer: London, UK, 2012; pp. 197-211. [CrossRef]

61. Ahmad, W.M.; Mourshed, M.; Mundow, D.; Sisinni, M.; Rezgui, Y. Building energy metering and environmental monitoring-a state-of-the-art review and directions for future research. Energy Build. 2016, 120, 85-102.

62. Barringer, F. New Electricity Meters Stir Fears. The New York Times, 2011; p. 30. Available online: https: / /www. nytimes.com/2011/01/31/science/earth/31meters.html (accessed on 20 December 2019). 
63. Sullivan, C.; Kahn, D. Smart Grid: Calif. Agency Mulls 'opt out'or Wired Substitutes as Fallout Persists. EEE News, January 2011. Available online: https://www.eenews.net/stories/1059944053 (accessed on 7 January 2020).

64. Opris, I.; Caracasian, L. The relation between smart meters and electricity consumers. In Proceedings of the 2013 12th International Conference on Environment and Electrical Engineering, Wroclaw, Poland, 5-8 May 2013; pp. 325-329. [CrossRef]

65. Bauer, P. A sequential elimination procedure for choosing the best population (s) based on multiple testing. J. Stat. Plan. Inference 1989, 21, 245-252. [CrossRef]

(C) 2020 by the authors. Licensee MDPI, Basel, Switzerland. This article is an open access article distributed under the terms and conditions of the Creative Commons Attribution (CC BY) license (http:/ / creativecommons.org/licenses/by/4.0/). 